\title{
ENTRE SUBJETIVIDADES ECONÔMICAS E ECONOMIAS SUBJETIVAS: O CAMELÓDROMO DE PORTO ALEGRE E AS EXPERIÊNCIAS DO PROCESSO DE TRANSIÇÃO
}

\author{
Moisés Kopper ${ }^{1}$
}

\section{INTRODUÇÃO: A EXPERIÊNCIA DA TRANSIÇÃO SIMBÓLICA}

Este artigo parte de uma pesquisa etnográfica sobre o camelódromo em Porto Alegre e as experiências do processo de transição neste contexto. ${ }^{2}$ É consenso entre os estudiosos do tema que as décadas de 1980 e 1990 - e, de maneira geral, o fim do século passado - foram pontuadas pelo avanço e consolidação, em nível mundial, das políticas neoliberais e de privatização das instituições públicas. Esse modelo de gestão político-econômico-estatal estabeleceu, também, num nível ainda mais fundamental, o caráter das relações entre a sociedade civil - particularmente os movimentos sociais e reivindicatórios de políticas públicas - e o Estado. A clivagem que se estabeleceu entre esses dois pólos fundamentava-se na crença de que existia, no âmbito particular das relações econômicas, uma lógica imanente, de caráter natural, que se incrustaria na sociedade de forma espontânea, desde que fossem os homens livres para agir na persecução de seus interesses utilitários. Da mesma forma, e não menos importante, essa "ordem" ou "precipitação" natural está amparada na crença de que seria a mais favorável para a prosperidade dos homens e das nações; por extensão, estaria acima de qualquer intervenção que o Estado pudesse realizar na vida econômica. O substrato que permanece subjacente, em ambos os pressupostos, é de que não haveria um antagonismo entre os interesses individuais e o interesse geral da sociedade: a harmonia economia seria a própria essência da ordem natural. Sem dúvidas, trata-se da relação postulada entre o individualismo utilitarista e o determinismo cultural a partir da qual o Ocidente se autoevidencia e se reconhece como sujeito (Sahlins, 1982).

Por sua vez, o projeto de concepção e planejamento de um Centro Popular de Compras que abrigasse os camelôs e comerciantes informais do centro de Porto Alegre não é um processo recente e precisa ser entendido a partir do campo de possibilidades

\footnotetext{
${ }^{1}$ Universidade Federal do Rio Grande do Sul, Brasil.

${ }^{2}$ Uma primeira versão deste artigo foi elaborada como monografia final do curso de Individualismo, Memória e Sociabilidade, ministrado pelas professoras Cornelia Eckert e Ana Luíza Carvalho da Rocha, do Programa de Pós-Graduação em Antropologia Social da Universidade Federal do Rio Grande do Sul (PPGAS-UFRGS), e apresentada no II Colóquio Individualismo, Sociabilidade e Memória. Agradeço, pois, aos comentários das professoras e, em especial, de Heitor Frúgoli Jr., com quem tive a oportunidade de debater os principais argumentos deste artigo.
}

Iluminuras, Porto Alegre, v.12, n. 28, p. 104-142, jul./dez. 2011 
macrossociológico que o instituiu. Se a sua implementação só se tornou possível nos últimos anos, é porque as alterações no modo de gestar e gerir a máquina estatal (Souza Lima, 2002) trouxeram novas questões, novas formas de administração de políticas públicas e, por extensão, novas "necessidades" e injunções para fazer cumprir e levar a cabo o processo de "reurbanização" e "higienização" da Região Centro de Porto Alegre ${ }^{3}$. Trata-se de compreender o processo de transição a partir de suas interfaces com as estratégias de governamentalidade (Foucault, 1979) associadas à força persuasiva do Estado: é no interior desse contexto mais amplo - que tem por escopo, entre outras coisas, a tentativa de produção de uma memória e de uma espacialidade legítimas baseadas no ideal da cidade cosmopolita e pretensamente multicultural - que a questão do camelódromo foi politicamente enunciada, discutida e implementada. O Estado opera, aqui, como um agente privilegiado nesse sistema de posições relativas, cuja constituição histórica não é menos relevante para o entendimento dos entrecruzamentos e tensionamentos entre as políticas públicas relativas às imagens associadas ao centro histórico e à ocupação do espaço urbano, de um lado, e os usos efetivos, individuais e coletivos, desenhados pelos cidadãos na arquitetura social e simbólica da cidade, de outro.

Não é por acaso, pois, que a Secretaria Municipal de Indústria e Comércio (doravante, SMIC) oferece novos cursos de profissionalização em outras áreas de atividade àqueles camelôs descontentes com seu Box no Camelódromo ou ainda àqueles que não garantiram a sua vaga em meio às 800 bancas previstas inicialmente pelo projeto. Uma segunda alternativa, mas não tão bem estimulada quanto a primeira, consiste no remanejamento dos desviantes para as ruas da periferia da cidade - a única alternativa ao centro que, de acordo com a política da prefeitura, deverá ser “devolvido" à "população" porto-alegrense. Restam desconhecidos, certamente, quais sejam esses cidadãos "mais humanos" em nome de quem o Estado se pronuncia e considera legítimo expropriar outros "cidadãos"4 - estes últimos, sem

\footnotetext{
${ }^{3}$ As principais modificações previstas pelo projeto de reurbanização do centro estão colocadas no programa "Viva o Centro", que "procura estimular, além do seu caráter predominantemente de comércio e serviços da área central, outras vocações importantes e compatíveis com seu potencial econômico, cultural e ambiental, melhorando as condições gerais do bairro. Volta-se, desta forma, para questões como a paisagem, a recuperação de prédios e áreas públicas, o transporte coletivo e individual, a segurança, a moradia e o comércio informal. $\mathrm{O}$ trabalho é desenvolvido através de um conjunto de ações”. Dados extraídos do site <http://www2.portoalegre.rs.gov.br/vivaocentro/>.

${ }^{4}$ A própria noção de ambulante, termo com o qual o Estado habitualmente se pronuncia para fazer referência aos comerciantes populares - ou camelôs -, carrega consigo uma conotação de expropriação, de alguém que, à maneira do exilado ou do expatriado, não é senhor de sua terra e, por conseguinte, não possui acesso à categoria de cidadão.
} 
dúvida, "menos humanos" - para enunciar, finalmente, seu conceito de cidade "multicultural".

O ponto fundamental está em que a instituição de um espaço de produção de pequenos comerciantes populares - em substituição à categoria de "camelô" - está amparada por um projeto moderno de legalização e visibilização da mão-de-obra trabalhadora, de vez que passa a concentrar vendedores "ambulantes" - isto é, dispersos pelas ruas, sem ponto fixo e, portanto, sem grandes chances de fiscalização legal contínua - em um único e denso espaço, em uma região geopolítica estratégica para a vigilância e o esquadrinhamento de suas movimentações e ações. Do ponto de vista subjetivo, porém, esse movimento objetivo traz um desajuste cognitivo que coloca em suspenso antigas categorias de avaliação e apreensão da realidade, ao mesmo tempo em que busca inscrever, nesse habitus em transfiguração (Bourdieu, 1983; 2001), novas estruturas ou parâmetros de inteligibilidade, associadas a mudanças em termos de projetos de vida, que se refletem também em modificações linguíísticas e perceptivas, isto é, no modo como tornam inteligíveis para si mesmos as novas experiências do estar na história e na modernidade, decorrentes da apreensão desse novo mundo objetivo.

Em outras palavras, isto implica investigar, num primeiro momento, de uma perspectiva ampliada, a constituição histórica da Região Centro de Porto Alegre e, com ela, o mapeamento social das múltiplas modalidades de agentes que a compõem através de seus deslocamentos e dos trajetos intersectados a que dão origem. O objetivo, aqui, é o de dar conta, historicamente, dos entrecruzamentos e tensionamentos das políticas de Estado (e os agentes estatais são, aqui, entendidos enquanto sujeitos privilegiados desse campo) e dos usos individuais e coletivos desenhados pelos transeuntes na arquitetura social e simbólica da cidade - de maneira a construir o contexto sócio-histórico de gestão da cidade que permitiu a emergência das políticas públicas de revitalização e urbanização do Centro. Como o Estado interfere nessa arquitetura social do espaço e do tempo da sociabilidade urbana em que a rua é o palco de atuação? Como, enfim, tratar das rupturas e contradições inerentes à multiplicidade dos pontos de vista que estão em jogo neste processo sem descurar do papel do Estado, que é convidado a intervencionar e a gestar, fundamentado num projeto pretensamente "social" de redistribuição econômica, as relações entre política e economia, entre o público e o privado e, finalmente, entre a constituição de narrativas e memórias sobre um processo socioeconômico de transição, e a configuração de uma frente discursiva, judicializada e estatizada, de 
elaboração dos limites e marcos legítimos em torno das expectativas desse mesmo projeto (Pollak, 1989) ${ }^{5}$ ?

Antes de dar seqüência à discussão, cumpre salientar que, do ponto de vista estrutural em que o Estado é autorizado a tomar posicionamento, é possível pensar o surgimento de uma espécie de "frente discursiva" em torno da constituição e consagração do Camelódromo enquanto instituição social - isto é, como um conjunto articulado e relativo de posições sociais, de agentes ocupando diferentes estratos desse sistema. A discussão dos critérios de operação e consolidação desta que é a primeira parceria público-privada da cidade ${ }^{6}$ permitiu a coadunação, de maneira indissociavelmente política e física, através da atuação pública, de pelo menos três modalidades de agentes. Há, de um lado, os agentes estatais (prefeitura municipal, secretarias de gestão, indústria e comércio, câmara de vereadores); de outro lado, os grupos sociais pleiteantes e afetados pelo processo - são estes os camelôs e comerciantes informais que durante várias décadas ocuparam as ruas do centro da cidade e que repentinamente se vêem na iminência dos processos de legalização e de negociação com o Estado, transfigurando uma relação historicamente pontuada pela oposição e pelo distanciamento sistemático da esfera pública. Há, ainda, um terceiro grupo de agentes - são os representantes da construtora do empreendimento - a empresa "Verdi Construções" -, com quem os camelôs deverão manter, doravante, uma relação contratual, jurídica e comercial de locação dos novos espaços de trabalho.

É no seio desta discussão que, de uma perspectiva micro-processual, torna-se possível perguntar acerca dos contextos em que é elaborada a paisagem imagética e mitoprática (Arantes, 2000; Bachelard, 1987; Simmel, 1996) que figura os contornos do deslocamento (de uma poética da rua transfigurada em prédio), a partir dos trajetos espaciais e temporais específicos (posto que demarcadores de quadros da memória) pelos quais os comerciantes populares se apropriam semanticamente dos novos espaços de ambiência da sociabilidade (que são também espaços de comércio, mas de fluxos de imagens e objetos constitutivos de

\footnotetext{
${ }^{5}$ Cf. Pollak (1989:8): “A fronteira entre o dizível e o indizível, o confessável e o inconfessável, separa (...) uma memória coletiva subterrânea da sociedade civil dominada ou de grupos específicos, de uma memória coletiva organizada que resume a imagem que uma sociedade majoritária ou o Estado desejam passar e impor".

${ }^{6}$ De acordo com o site da prefeitura de Porto Alegre, uma PPP "é uma parceria onde o setor privado projeta, financia, executa e opera uma determinada obra/serviço, objetivando o melhor atendimento de uma determinada demanda social. Como contraprestação, o setor público paga ou contribui financeiramente, no decorrer do contrato, com os serviços já prestados a população, dentro do melhor padrão de qualidade aferido pelo Poder concedente". No caso do Camelódromo, trata-se de uma concessão de área pública à iniciativa privada, que poderá explorar integralmente o espaço durante 25 anos, sem contrapartida financeira direta do poder público sobre esses encargos de locação.
} 
um comércio dependente e construído a partir desses itinerários e movimentos pelas ruas, calçadas, bancas do Camelódromo). Se, como quer Sahlins (1997), a conjuntura atual impõe a investigação dos múltiplos processos de indigenização do mundo moderno, então uma das chaves interpretativas para a compreensão dos significados da atuação desse movimento social, tendo por pano de fundo a implantação de um modelo específico de camelódromo, está em partir, do ponto de vista metodológico, de suas estratégias de "resistência cultural ". É aqui que localizamos as táticas locais que autorizam fundar "trajetos de resistência", isto é, espaços-tempos que se entrechocam e que se inscrevem nos interstícios e fronteiras do poder esquadrinhador do Estado.

Privilegiar os trajetos de resistência cultural implica decompor o processo de transição ao Camelódromo tendo em vista pelo menos quatro dimensões propriamente etnográficas, isto é, que colocam em evidência a atuação estratégica dos agentes sociais diretamente implicados no processo de transposição. A primeira delas diz respeito à manipulação das finanças e, mais diretamente, dos usos particulares do dinheiro e das estratégias de comercialização - há, inevitavelmente, um projeto econômico-pragmático fundamentado numa perspectiva ocidental moderna de lidar com o tempo, o dinheiro e, por extensão, de projetar o futuro. Em segundo lugar, há a transfiguração dos processos de socialização e das redes de reciprocidades e alianças que orientam as tomadas de posição, movimentações e estratégias políticoeconômico-sociais vigentes entre os camelôs. A questão cultural-simbólica, por sua vez, trata dos aspectos concernentes à subjetividade, aos projetos culturalmente mediados, aos dramas e às narrativas performáticas empreendidas pelos agentes ao ordenarem as distintas experiências vividas com esse deslocamento. Finalmente, não menos importante, tem-se o processo de politização dessa experiência, através da discussão e negociação pública (isto é, nos espaços da democracia participativa e representativa da cidade, tais como fóruns do Orçamento Participativo, comissões da Câmara de Vereadores, gabinetes de autoridades governamentais, reuniões e assembléias) das perspectivas e critérios associados aos critérios de acesso ao projeto, bem como à narração e enunciação do processo de transição.

Se, de uma perspectiva sociológica, um ponto de partida importante está, como vimos, em reconstituir o campo de forças em torno do qual gravita o processo de transição ao Camelódromo e que o consagra enquanto sistema social total (ampliando o prisma a partir do qual se delinearam as disputas e negociações relativas à dinâmica da urbanização), a investigação antropológica que toma como princípio heurístico uma hermenêutica dos 
"relatos" ou "percursos" de espaço (De Certeau, 1994: 182-198), singulares e subjetivos, que conferem sentido a cada uma dessas modalidades de agências do campo de posições, não se faz menos relevante. Trata-se de pensar a construção desses diferentes engajamentos como geradores de um determinado self, cuja identidade (coletiva ou individual) passa pela organização e constituição do itinerário particular da transição e, por extensão, da própria instauração de um percurso topográfico (uma "caminhada") que coloca o corpo e as categorias cognitivas em movimento e que extrapola, assim, o afã demarcatório do mapa tópico e definidor de posições. Se o Estado constitui a sua agência por meio da instituição e definição de lugares demarcatórios (a própria transição é apresentada não como movimento, mas como mudança, ancorada em datas e prazos que demarcam a desocupação da rua e sinalizam a imediata inauguração de um novo espaço que já se presume imediatamente ocupado), por outro lado importa, aqui, colocar luz sobre os processos de construção dessa transição, da elaboração de uma temporalidade e espacialidade sui generis que se sobreescreve às injunções estatais e que funda, ou melhor, coloca em dinâmica, as categorias localizadoras do Estado, sob a forma de transição transgressora, isto é, de um deslocamento simbólico que extrapola os limites do lugar.

Se é legítimo pensar o processo de transição como uma espécie de ritual de liminaridade expandido, pois que institui uma temporalidade nova nos interstícios de dois pontos fixos da estrutura (o antes da rua e o depois do Camelódromo) (Turner, 1974; 2008), então a investigação hermenêutica (Geertz, 1989) em torno dos símbolos visuais e auditivos que pontuam essa experiência é imprescindível para a compreensão da eficácia simbólica que resulta da acomodação dessas novas experiências no seio de cada indivíduo que as realiza. Essas figuras, esses mitos tornados prática (mitopraxis), enfim, essas narrativas imagéticas pelas quais a transição subjetiva às novas condições objetivas é realizada, operam culturalmente como dispositivos mnemônicos, ou "depósitos" de informação, não sobre técnicas pragmáticas, mas sobre cosmologias, valores e axiomas culturais, por meio dos quais o conhecimento profundo da experiência do pertencimento a uma dada comunidade é transmitida entre os seus membros. Este é, pois, o ponto que nos interessa ao investigar a maneira como são acionadas, pelos comerciantes populares que venho acompanhando, determinadas simbologias, discursividades ou práticas culturais na constituição do processo de transição. É, portanto, na incorporação dos códigos sensoriais subjacentes aos detalhes do mito e do rito, bem como nas homologias entre eventos e objetos descritos em diferentes 
códigos $^{7}$ - visuais, auditivos e táteis -, que se desenha a temporalidade deslocada do ritual da transição.

Há, assim, uma série de símbolos, materializados ou imaginados, que operam como configuradores de fronteira, que criam um relato de interações e de transições, ao mesmo tempo em que mediam e articulam, isto é, criam uma comunicação metafórica que separa a imagem do passado e do devir. Se a pulsão do arquiteto e do paisagista consiste em trabalhar o congelamento político dos lugares, por meio da construção dos pontos ou lugares estruturais, cabe à fronteira constituir o espaço-tempo da transição, em que o jogo de interações e de entrevistas se configura como símbolo narrativo de intercâmbios e encontros.

Há por toda parte a ambigüidade da ponte, que ora solda ora contrasta insularidades. Distingue-as e as ameaça. Livra do fechamento e destrói a autonomia. (...) Dá prosseguimento a uma vida dupla em inumeráveis memórias de lugares e legendas cotidianas, resumidas muitas vezes em nomes próprios, paradoxos escondidos, elipses de histórias, enigmas pedindo decifração (...). Transgressão do limite, desobediência à lei do lugar, ele representa a partida, a lesão de um estado, a ambição de um poder conquistador, ou a fuga de um exílio, de qualquer maneira a 'traição' de uma ordem. Mas ao mesmo tempo ergue um alhures que extravia, deixa ou faz ressurgir, fora das fronteiras, a estranheza que era controlada no interior, dá objetividade (ou seja, expressão e representação) à alteridade que se escondia do lado de cá dos limites, de sorte que, cruzando a ponte para lá e para cá e voltando ao recinto fechado, o viajante aí encontra agora o outro lugar que tinha a princípio procurado partindo e fugido depois voltando. (...) Tudo ocorre como se a própria delimitação fosse a ponte que abre o dentro para seu outro (De Certeau, 1994:196-197).

Trata-se, aqui, de trazer à tona uma investigação acerca do sentido e do estatuto simbólico dessas figuras e imagens mitopráticas que povoam a própria liminaridade do deslocamento: é o símbolo em sua muti-dimensionalidade inexaurível e interior (Durand, 1988; 1989) que é preciso buscar a partir do exame dos signos exteriores - entendidos como significantes arbitrários e metafóricos de processos cognitivos que são, ao mesmo tempo, corolário e condição de percepção da transição. Essas operações de demarcação condensadas nos relatos e imagens são compostas de fragmentos tirados de histórias anteriores e "bricolados" num todo único e irredutível às partes: são esses diversos elementos ou fragmentos de realidades e pensamentos (como no pensamento concreto em Lévi-Strauss), extraídos de outros contextos e planos cristalizados de significado (tal qual "territórios", "pontos brilhantes", instantes da memória) em que a memória é chamada a atuar, no e pelo instante presente, por meio de "pontos de amarração", que conformam o contexto sui generis

${ }^{7}$ Lévi-Strauss (1989) diria: no próprio processo de fabricação e organização dos elementos constitutivos do bricoleur e da lógica do pensamento concreto. 
da transição simbólica (Bosi, 1987). Trata-se de pensar, pois, a mútua articulação (bricoleur) entre acontecimentos, espaços e lugares, na medida em que participam da trama que resulta dos trabalhos da memória, elaborada a partir da perspectiva de um narrador que seleciona criativamente pontos e objetos particulares no espaço (convertido então em paisagem) e no tempo contado. Esse trabalho criativo de memória perdura (tem uma certa duração própria, uma ritmicidade, uma vibração), então, na estruturação das práticas futuras (Arantes, 2000).

Nesse sentido, as "operações de demarcação" esclarecem a estrutura da narração enquanto mitopráxis (Sahlins, 1990), isto é, enquanto fundadora e articuladora de espaços simultaneamente imaginados e concretizados: de fato, o relato não somente descreve, mas também fixa lugares e, com isso, institui os jogos de espaço; toda descrição é, antes de tudo, portanto, um ato culturalmente criador, que abre um "teatro" de legitimidade a ações efetivas por meio da criação de um campo que autoriza, como veremos, práticas sociais arriscadas e contingentes (De Certeau, 1994).

\section{A FIGURA DO LÍDER E A DRAMATIZAÇÃo NARRATIVA DA TRANSIÇÃo}

Se a transição cria, fundamentalmente, uma experiência coletiva (Halbwachs, 1990) e ritual que transforma a percepção porque modifica os princípios de seleção da realidade (Douglas, 1966), ela só o faz na medida em que institui um espaço de interação e interlocução entre sujeitos, a partir de cujos entrecruzamentos são elaboradas as imagens e narrativas desse deslocamento. De fato, um dos aspectos distintivos deste constante betwixt-and-between entre fronteiras está em que a construção dos itinerários e fluxos da transposição é formulada concomitantemente à própria produção do sentido de pertencimento grupal e, por extensão, na experiência coletiva e comunitária de construção das categorias de apreensão da realidade. Isto significa que, antes de atentarmos para as imagens da transição, é preciso levar em conta que o tensionamento das fronteiras entre informalidade e legalidade, do ponto de vista da identidade coletivamente formulada nesses novos espaços, coloca em cena a figura do líder comunitário, ao qual cabe gestar e canalizar a economia moral e emocional do grupo em torno da formação de uma comunidade afetiva de pertencimento que possibilite a estruturação simbólica da transposição. É através de sua agência, ainda, que são conduzidas as negociações e disputas - que não se encerram enquanto não estiver concluído o ajuste subjetivo dos sujeitos afetados às novas condições objetivas - por fora do Camelódromo, isto é, na articulação de diferentes espaços da esfera pública (Câmara Municipal, Ministério Público, 
Prefeitura, Orçamento Participativo), por cujos interstícios as expectativas e insatisfações do grupo são orientadas, e suas narrativas de transição, mais bem formuladas.

O ponto fundamental a ser observado é que a constituição coletiva dos símbolos narrativos da experiência de transição - intermediada pela emergência do líder comunitário sintetiza apenas uma das múltiplas possibilidades de construção do ajuste simbólico das novas condições objetivas propostas pelo deslocamento ao Camelódromo, referenciada, por sua vez, a um mecanismo particular de formulação identitária do self (Taylor, 2005) e do estar na história. O conceito de região (De Certeau, 1994) ou, mais concretamente, de sistema de posições associadas a um campo de forças sociais (Bourdieu, 1983; 2007) permite dar conta dessa diversidade polivalente de espaços de formação e entrecruzamento de sociabilidades, de projetos de vida, de campos de possibilidades (Velho, 1981; 1994) e de processos de subjetivação (Foucault, 1984; 1985) que subjazem à dinâmica dos agentes da transição. Tratase de um espaço criado por uma interação e que, nos múltiplos encontros entre programas, conformam a dinâmica de um dado lugar. Se a determinação desse espaço é interlocutória, isto é, obedece ao fluxo dual e operacional desses entrecruzamentos, é porque ele admite certa plasticidade e maleabilidade em termos dos projetos, dos campos de possibilidades e, mais especificamente, dos processos de subjetivação que subjazem à dinâmica dos agentes da transição. Qual é, afinal, o sujeito dessa transição?

Uma investigação etnográfica das disputas que vêm sendo travadas desde o processo de discussão dos critérios de acesso e implantação do Camelódromo, passando por sua efetiva implementação, deixa entrever as noções de pessoa (Dias Duarte, 1986; Dumont, 1985; Goldman, 1999; Mauss, 1974) que subjazem às elaborações narrativas de resistência ao enquadramento. O contraste entre duas modalidades de atores sociais - cujos "tipos ideais" são condensados pela agência das próprias lideranças que representam cada uma das comunidades de sentido - operará, nessa perspectiva, como ponto de apoio para a problematização da tensão entre o projeto individualista do comerciante popular autônomo, de um lado, e o projeto identitário e coletivo dos camelôs refratários aos encargos simbólicos e pragmáticos demandados pela legalização de suas práticas, de outro.

No seio da clivagem entre os blocos A e B do empreendimento ${ }^{8}$ - que significa, também, uma sedimentação entre as várias perspectivas de atuação política e social dos ${ }^{8} \mathrm{O}$ camelódromo conecta a Avenida Voluntários da Pátria à Mauá, através de uma passarela de dois corredores
que entrecruzam a avenida Julho de Castilhos -, ao mesmo tempo em que estabelecem uma clivagem entre os 
comerciantes -, venho acompanhando etnograficamente as manobras e os itinerários de um grupo de camelôs que estiveram à testa da discussão dos processos de implementação do Camelódromo em Porto Alegre. Trata-se da Associação Feira Rua da Praia (ASFERAP), fundada em 2001 pelo seu atual presidente - Juliano Fripp -, com o objetivo inicial de escapar ao rótulo estereotipado da categoria de "camelô", valendo-se, em detrimento, da expressão - politicamente mais polida e amena - de "feirante" para justificar a sua atuação ao longo da rua dos Andradas, localizada no centro da capital gaúcha. Seus pouco mais de duzentos membros, de início constrangidos pelo carregada expressão "camelô" - já que, como micro-produtores independentes de artigos de vestuário, consideravam-se algo "mais" que vendedores de quinquilharias - passariam, com a implantação e as conseqüências do projeto do Camelódromo, a reinventá-la e mesmo invocá-la em favor de uma categorização identitária do movimento social, como o baluarte das lutas e disputas políticas que seriam travadas para resguardar seu direito de permanência nos boxes do shopping popular.

A trajetória da transição e os significados desse percurso de resistência, tornada inteligível pelos usos estratégicos e públicos da palavra narrada e pela circulação por diferentes espaços públicos de Porto Alegre, pode, assim, ser mais bem descrita a partir dos itinerários de Juliano Fripp e de sua comunidade. De modo que tais contextos se convertem em dispositivos de acesso privilegiados aos processos mais amplos de disputas a partir dos quais a performance tem fundamento; isto é, como um ponto de vista particular, ainda assim coletivo - como uma dada posição social no campo de forças e de possibilidades culturais -, que é atravessado pelos processos globais e macro-sociológicos em desenvolvimento, num dado recorte temporal e espacial específico. Filho de pequenos agricultores, atualmente residente em Esteio, região metropolitana de Porto Alegre, Juliano, como liderança comunitária, intersecta em suas movimentações e estratégias discursivas uma diversidade de agentes e instituições sociais.

Começar a falar em Camelódromo, pra mim, pra muitos é bem antes, mas pra mim é falar em 1990, quando a gente foi pra Rua da Praia trabalhar com o comércio informal, por uma questão de necessidade pura, por não ter emprego (...). E lá a gente encontrou muita gente como a gente, que por necessidade extrema acabam indo pra rua, porque é a única forma que as classes dominantes deram pra nós e continuam dando. Então na rua a gente achou a

blocos A e B do empreendimento. Simultaneamente uma divisão física e metafórica, cumpre observar, do ponto de vista antropológico, as apropriações simbólicas dessa diferenciação, isto é, os modos pelos quais as diferenças na alocação e distribuição de comerciantes populares oriundos de diferentes segmentos da rua e perspectivas de engajamento são ressignificadas, com base na arquitetura e dos espaços estratégicos do prédio, em termos de uma oposição entre o bloco A e o bloco B do prédio. 
dignidade, a maneira de poder trabalhar e sobreviver. Então esta luta começa desde 1990, a gente se organizando pra chegar o momento de que os espaços que a gente pudesse trabalhar fossem dignos, um espaço que a gente pudesse mostrar pra sociedade o valor que nós temos ${ }^{9}$.

O debate dirigido em torno da concepção de um projeto de Camelódromo que acomodasse grande parte do trabalho informal distribuído quase que aleatoriamente pelas principais calçadas e avenidas do centro da cidade ganhou forma a partir de 2002, com a elaboração de um shopping vertical fundamentado no projeto arquitetônico de Belo Horizonte, que viria a ser apresentado em 2005 aos então “ambulantes" pela Secretaria Municipal de Produção, Indústria e Comércio (SMIC).

Aí a gente já via a ânsia dos políticos, a ânsia da sociedade, de tirar nós da rua. E começamos desde aquela época a se organizar pra ter esse espaço digno. (...) Fizemos uma grande manifestação em Porto Alegre rechaçando a idéia do Camelódromo vertical. Fizemos uma grande passeata, lotamos o plenário, entregamos um abaixo-assinado com $15 \mathrm{mil}$ assinaturas, dizendo que espaço de camelô era na rua! Era espaço horizontal! E partir daquele momento surgiu a idéia do camelódromo horizontal na Ruy Barbosa. (...) E nós, AFERAP, com muito orgulho, aceitamos, porque ali a gente via um espaço horizontal digno dum grande movimento, que atraía muitas pessoas pro seu terminal pra continuar sendo nossos clientes. A partir desse momento a gente começou a trabalhar com o secretário Leo Bulling a construção do projeto desse camelódromo ${ }^{10}$.

Com efeito, as incursões entrecruzadas de diferentes segmentos representantes do comércio informal - entre os quais, destacadamente a ASFERAP, através da agência discursiva de seu presidente fundador - produziram uma série de disputas e negociações que envolvem o acionamento reiterado de múltiplas esferas do Estado e da Justiça, cuja análise exaustiva escapa aos objetivos circunscritos por este artigo ${ }^{11}$. O ponto a destacar, contudo, está que tais contextos de discussão permitiram ao líder comunitário a experiência subjetiva da participação na tomada pública das decisões a respeito da condução da política paisagística, arquitetônica, social e econômica da cidade, de tal forma que lhe autoriza colocar

\footnotetext{
${ }^{9}$ Excerto de discurso proferido durante Reunião na Comissão de Direitos Humanos/Câmara, 28/08/2008.

${ }^{10}$ Excerto de discurso proferido durante Reunião na Comissão de Direitos Humanos/Câmara, 28/08/2008.

${ }^{11} \mathrm{Um}$ dos espaços privilegiados de enunciação e problematização dessas questões, ao longo dos anos prévios à inauguração da obra, e que representou, para a ASFERAP, um dos elementos fundamentais de instrumentalização e empoderamento para a realização desse debate (tanto em termos das possibilidades de discussão do tema, quanto em relação às habilidades discursivas acionadas para a expressão na arena pública), foi o Fórum Regional de Delegados e Conselheiros (FROP) da Região Centro do Orçamento Participativo de Porto Alegre. Ao longo dos dois anos em que acompanhei sistematicamente as reuniões semanais realizadas na Sala 10 do Mercado Público, observei a dinâmica da constituição e do rompimento estratégico das alianças e reciprocidades que se desenhavam em torno da discussão sobre a finalização da obra, de um lado, e a tensão subjetiva da transposição, de outro. Juliano, de forma particular, ocupou as instâncias diretivas do FROP Centro como delegado e conselheiro durante vários mandatos consecutivos, além de ter participado, no último mandato, como conselheiro da Temática de Desenvolvimento Econômico.
} 
a questão como resultado de um acordo de diferentes partes, em que a sanção e a deferência da ASFERAP desempenharam, supostamente, papel central. É a partir desta experiência, pois, que a aceitação do projeto horizontal de camelódromo adquire sentido. Não obstante, trata-se, aqui, apenas, de um acolhimento parcial, posto que dependente de quais sejam as condições simbólicas relativas à preparação do processo de transição, e a quem caberá enunciá-las. Se a aliança com os agentes estatais se faz possível, ela só pôde se tornar pensável na medida em que representou a possibilidade remota de barganha dos termos e critérios objetivos do deslocamento $^{12}$.

Aí começa uma luta que a gente desde o início acreditou que seria verdadeira. (...) Assim como os vereadores acreditaram nesse camelódromo, nós também acreditamos nele. Acreditamos que as propostas que a gente tava levando pro então secretário seriam aceitas. Acreditamos que os espaços seriam de 2 por 2 . Acreditamos que o valor seria de $\mathrm{R} \$ 200$ a $\mathrm{R} \$ 250$. Acreditamos que a gente teria acesso à engenharia da obra, porque é a nossa segurança, de quem vai estar lá dentro daquele espaço, que ta em jogo. Só que nada disso aconteceu! (...) Nós entramos na justiça, e infelizmente perdemos na primeira instância! E fomos lá escolher os pontos porque a SMIC ia usar isso contra nós. Nós chamamos a ASFERAP e fomos lá escolher os nossos pontos, os últimos a escolher, os últimos! Porque a gente tentou até o fim! Escolhemos o nosso ponto pra não perder. Mas mesmo assim a gente não se entregou e não vai se entregar.

$$
* * *
$$

Alfonso Limberger é representante da "Associação Comercial do Centro Popular de Compras", que reúne cerca de 300 comerciantes populares; atua também como conselheiro titular da Temática de Desenvolvimento Econômico, Tributação e Turismo do Orçamento Participativo de Porto Alegre; e foi coordenador, durante vários anos, da Comissão "Praça XV, José Montaury e Vigário José Inácio”, a partir de cuja perspectiva participou dos debates relativos à instituição do Camelódromo. Este é um dos atores sociais de destaque com quem Juliano disputa a hegemonia e o monopólio da representação dos comerciantes populares. Alfonso foi um dos primeiros comerciantes a se instalar, há mais de 25 anos, na Praça XV, em oposição a Juliano, liderança de ascensão e articulação mais recente, cuja associação de camelôs foi fundada há menos de 10 anos. Suas posições quase antagônicas na maioria dos assuntos concernentes ao Camelódromo - e à política de maneira geral -, refletem espaços de posicionamentos sociais heterogêneos, que conduzem a diferentes estratégias de enunciação e

\footnotetext{
${ }^{12}$ Durante todo o ano de 2008, a constante exposição à mídia em função dos conflitos com outros setores e agentes sociais envolvidos na disputa pelo Camelódromo, bem como as diversas manifestações públicas em favor da rediscussão do projeto e da transposição dos camelôs, fizeram-no candidatar-se a vereador de Porto Alegre, pelo PCdoB. Apesar de seu prestígio político e das várias incursões durante a campanha pelas comunidades da Região Centro do OP, em que se consolidou como liderança, Juliano fez cerca de 900 votos, o que o colocou numa distante posição de suplência, muito aquém de suas aspirações iniciais.
} 
construção do self. Enquanto Juliano era favorável à utilização do sorteio como critério de divisão e concessão das bancas, Alfonso defendia o critério de antigüidade como legítimo. $\mathrm{O}$ voto de minerva, que coube à Prefeitura Municipal, através da SMIC, instituiu o tempo de permanência na rua como o critério mais adequado para a divisão dos espaços. Desde então, as disputas e posicionamentos de cada um dos líderes tem sido associadas a facções e clivagens políticas - Alfonso, que desde o início da concepção do empreendimento procurou minorar e obscurecer os problemas apontados por Juliano, passou a ser identificado como representante do governo na decisão e nas negociações em torno da questão. Juliano, que, vinculado à ASFERAP, obteve os pontos de menor prestígio e visibilidade, atribui o fato a reveses políticos e a negociações de bastidor, atravessadas por tais pertencimentos estratégicos que fundamentam o campo da política convencional. De forma que se instituiu, do ponto de vista discursivo e das estratégias de politização e instrumentalização dos símbolos da transição nos espaços da esfera pública, uma antinomia entre os pertencentes à facção governamental e aqueles cuja sensibilidade e mediação política estariam voltadas proeminentemente à comunidade de camelôs afetada pela implantação do projeto no centro da cidade.

Se, por um lado, Juliano e Alfonso podem ser entendidos como arquétipos de posicionamentos estratégicos relativos ao processo subjetivo de transição, enquanto lideranças que consolidam e concentram em seu entorno modalidades distintas de produção do self, da individualidade e da sociabilidade nesses espaços, por outro lado as diferenças no processo de constituição dos atributos e das habilidades que os transfiguram em atores sociais destacados obedece a lógicas distintas que, em última instância, fazem referência a duas perspectivas antagônicas de concepção da cosmologia moderna de experiência da legalidade. O itinerário de Alfonso, desde o período anterior à inauguração do prédio, era pontuado por entrevistas em diferentes veículos de comunicação, acentuando as consequiências positivas e construtoras de um sentido autônomo de individualidade materializado na própria fluidez e naturalidade com que empregava, discursivamente, a categoria de "comerciante popular". Trata-se, aqui, de forjar e gestar, criativa e individualmente, uma nova interioridade pela qual a experiência da transição adquire sentido quase imediato: o projeto da translocação, gestado no interior de um campo de possibilidades afeito e simpático ao movimento ascético do empreendedor comercial, é elaborado progressivamente ao longo dos meses que antecederam à inauguração e adquire a idéia de uma mudança global das condições objetivas e subjetivas de vida. Nesse 
caso, portanto, a transição equivale à preparação e elaboração imagética de um futuro esperado e projetado, em que o ritual da inauguração do prédio aparece apenas como a passagem instantânea para uma nova fase cuja absorção e realização das condições objetivas encontra correspondência no sujeito que as desejou e imaginou (Berger e Luckmann, 1983; Schütz, 1979).

Alfonso é o protótipo do bom cidadão ideal e convertido, cujas estratégias de transição encontram respaldo nos itinerários e trajetos de vários outros comerciantes populares cujo "sucesso" em termos de comercialização foi apenas alimentado e encontrou correspondência nas expectativas subjetivas que gestavam desde a concepção do projeto: aqui, não é tanto a percepção e a realização das mudanças objetivas (em termos de uma readequação total do perfil da clientela, da estrutura física do prédio e, conseqüentemente, da oferta de mercadorias específicas) que conduz e explica o sucesso, mas, antes, a predisposição à aceitação do projeto como produtor de positividade, isto é, de um novo sujeito que é capaz de atribuir a todas estas mudanças o sentido do "progresso", da "dignidade", da ascensão social, enfim, da percepção e do léxico do "sucesso". Que o fluxo de vendas diminua ou varie em relação às expectativas de propulsão arquitetadas em relação às condições encontradas outrora na rua, isso não é atribuído a pretensas falhas de projeção do que é estar no Camelódromo; a predisposição subjetiva à aceitação das novas condições de comercialização e sociabilidade permite que os entraves e problemas que emergem no traçado desse deslocamento para a legalidade sejam definidas e situadas, invariavelmente, no sujeito que as experimenta: é porque o sujeito não se adequou completamente à imagem do novo comerciante e, logo, porque a transição não foi completamente incorporada, que as vendas não alavancaram. De mais a mais, não é o utilitarismo que explica a conversão ao Camelódromo: não se trata de reduzir a aceitação ou o rechaço ao arquétipo do cidadão comerciante como diretamente proporcional à intensidade dos fluxos de comercialização. Não deixa de ser significativo que, no protótipo encarnado por Alfonso, mesmo os períodos de baixo fluxo de comércio não se traduzam em pretextos para críticas ao projeto (ao contrário, elas estimulam novos esforços de conversão às estratégias do modelo gestado pelo Estado); e, inversamente, no protótipo materializado por Juliano, também os períodos de intensificação do fluxo de comércio não deslegitimam as diversas estratégias de condenação do modelo autônomo e individualista de comerciante (ou seria micro-empresário?) popular. 
De fato, a adesão incondicional ao léxico do "sucesso" coloca em jogo a necessidade de superação dos entraves à conversão: não é que as condições objetivas da transição (como os encargos com alugueis, as novas obrigações em termos de horários, práticas, técnicas e expectativas de comercialização) não desempenhem um papel importante no processo de aceitação do projeto, mas, antes, que não se pode explicar a predisposição subjetiva à incorporação dessas injunções exclusivamente por uma avaliação de custo-benefício economicamente direcionada. Deste ponto de vista, a adesão total à perspectiva individualista traz consigo, também, a incorporação dos sacrifícios e ônus necessários ao usufruto da categoria de "cidadão de direitos" (fundamentada, por sua vez, na instrumentalização de uma série de símbolos econômicos que conferem prestígio, status e "dignidade" a esse indivíduo em gestação), percebidos em seu aspecto de positividade, de forjadura desse novo sujeito.

Alfonso não é um líder particularmente dotado de habilidades de condução e manipulação das fronteiras de uma comunidade de pertencimento simbólico, entre outras coisas, porque a natureza de sua liderança não lhe demanda o emprego de tais competências: trata-se, aqui, de gerir não uma comunidade (que representaria uma experiência coletiva de transição), mas o ajuntamento de um grupo de indivíduos em gestação, compartilhadores de uma mesma predisposição subjetiva acerca do projeto do Camelódromo e que, uma vez resolvidas as pendengas relativas ao processo de conversão, poderão tratar do que "realmente importa": o fluxo de vendas comerciais. O trabalho de Alfonso, enquanto líder, consiste, então, em captar, através de suas circulações pelos bastidores do Camelódromo, este novo perfil de comerciante popular autônomo, e canalizar suas expectativas por intermédio da associação que preside, ao oferecer inúmeras vantagens, todas de caráter econômico. É a conversão à lógica utilitária do processo econômico da circulação de mercadorias que sinaliza, pois, neste caso, a finalização bem-sucedida do processo de transição.

Ao contrário, a comunidade de pertencimento que se concentra em torno da figura do líder comunitário - nomeadamente, como é o caso, aqui, de Juliano - lhe demanda, entre outras habilidades, o exercício da palavra como instrumento de legitimação e instituição das fronteiras simbólicas para o entendimento da experiência da transição. Deste ponto de vista, o líder comunitário figura como um narrador privilegiado - não somente porque a ele são dirigidas as expectativas em torno do uso da palavra, mas sobretudo porque são os seus atos de enunciação que instituem e dão o tom da temporalidade particular que caracteriza o processo de transição daquela comunidade de comerciantes populares. É através do emprego 
de certas técnicas narrativas e habilidades performáticas - que visam, entre outras coisas, articular eficazmente diferentes universos simbólicos - que o líder comunitário constitui de um lado, a sua reputação enquanto mediador político e, de outro, o espaço dos possíveis para a dramatização narrativa dos símbolos e das imagens da transição. A eficácia simbólica do discurso ritual depende, assim, de fazer articular estrategicamente - isto é, de acordo com cada espaço ou campo de atuação - o tempo específico do ato enunciado com a manipulação do tempo do próprio ato de narração (Ricoeur, 1994). É desse ajuste que resulta a produção de sentido sobre o processo simbólico da transição.

A dinâmica das relações entre a construção coletiva de apropriação simbólica do projeto do Camelódromo e as implicações deste campo de possibilidades em termos das formas de sociabilidade poder ser mais bem sintetizada no próprio uso discursivo de Juliano da categoria "camelô", em oposição à de "lojista" ou de "empresário". Trata-se, aqui, de um jogo estratégico e ambivalente que o líder sabe ser de alto valor simbólico: ao mesmo tempo em que não se está preparado para assumir os encargos financeiros e simbólicos da nova posição social e cultural que a figura do "comerciante" impinge, Juliano também não despreza - chegando, inclusive, a postular - as novas prerrogativas e vantagens que a mudança de status institui: “Aqui nós somos diferenciados!”. É uma articulação e uma tomada de posição sobre a questão que tem em vista as sensações, as impressões e os impactos subjetivos do processo de transposição, e que pressupõem o acionamento dinâmico e concomitante do léxico individualista e holista (Dumont, 1985) na definição dessa diferenciação como a espessura da fronteira que caracteriza a ambivalência existencial de seus interlocutores - que não se situam, ainda, nem aqui nem lá (Turner, 2008), mas neste espaço de liminaridade e transitoriedade simbólica entre o universo anônimo da rua e o universo da visibilidade e da legalidade intrínseco ao Camelódromo. É, portanto, esse jogar e flertar estratégica e parcialmente com cada um desses universos de significado, sem comprometer-se a uma adesão axiomática e irreversível, que caracteriza a própria natureza da transição enquanto uma fronteira que promove a mediação e articulação (De Certeau, 1994).

Do ponto de vista das imagens e narrativizações associadas ao processo de transição, estaríamos mesmo tentados a afirmar que, de fato, pelas estratégias simbólicas que faz empregar, esse deslocamento produz uma nova apreensão cosmológica da realidade que, além do mais, atravessa a constituição desse novo self - coletivo ou individual - em desenvolvimento e movimento simbólicos. A narração ilustra assim, ao mesmo tempo em que 
extrapola os limites do discurso para concentrar-se no símbolo, uma inversão da espacialidade e do tempo em relação à experiência da rua: se na rua tratava-se de ocupar o lugar, espacializando-o com seus circuitos, apropriando-se com as redes de sociabilidade cujo entretecimento e margem de manobra pareciam irrestritas e quase atemporais, no camelódromo é a delimitação do tempo que ocupa lugar central e constrange os movimentos possíveis de espacialização. Sobretudo, é a racionalização e a preeminência da percepção do tempo enquanto categoria social que decompõem o ciclo espacial e social da rua em linhas contínuas, horizontalizadas, padronizadas, estendidas uma ao lado das outras para a produção da visibilidade e da maximização da distribuição física do espaço. São as tentativas de homogeneização da percepção do tempo e do espaço que se pretendem extensões materializadas da autonomia, da isonomia, da equanimidade, enfim, da clássica relação indivíduo-sociedade que tão bem caracteriza o modelo funcional-estruturalista - e, por extensão, individualista - do sujeito no mundo. São essas tentativas que, igualmente, dão fundamento ao trabalho de mediação, de transição, de articulação em que o líder desempenha papel significativo, na medida em que permitem instituir uma conciliação criativa e dinâmica através do relato, da significação simbólica, da narração da experiência que institui uma disposição do tempo e do espaço a meio caminho entre a rua e o camelódromo.

\section{O PROCESSO DE PREPARAÇÃo E O INÍCIO dO PRIMEIRO CICLO DE TRANSIÇÃo}

O mês de dezembro de 2008, não obstante o excelente fluxo de vendas que caracteriza essa época sazonal do calendário comercial (in)formal, não elidiu a formação paulatina do estado de liminaridade social, desencadeado pela iminência da ruptura para com a rua (afinal a inauguração do prédio era concomitante à promulgação da lei que proibia o comércio nas ruas do centro da cidade), e o estabelecimento de um novo horizonte de percepção ou imaginação (Crapanzano, 2005). Os jornais da época não cessavam de revelar as manifestações de insatisfação e insegurança que tomavam conta dos camelôs afetados, perfilados no entorno da Praça XV, da José Montauri, da Vigário José Inácio, da Feira da Rua da Praia, da Praça Osvaldo Cruz, da Campos Sales, ou da Feira da Praça da Alfândega. Aos poucos, surgiram as primeiras contestações abertas ao projeto de formação de microempresários, na medida em que implicava, por extensão, a extinção da categoria "camelô"; as primeiras formulações em torno da reivindicação de um prazo de carência do valor dos 
alugueis, bem como da revisão e do zoneamento dos seus valores, adquiriram voz no discurso dos líderes de algumas associações de camelôs, entre as quais a própria ASFERAP.

Em uma de minhas várias incursões pela região centro, em meados de 2008, encontrei Juliano fazendo os últimos preparativos para a entrega de sua documentação na SMIC, para o cadastramento dos comerciantes populares que ocuparão os boxes do camelódromo. O dia ainda era de campanha eleitoral, um sol escaldante que não dava trégua diante da movimentação e da intensidade dinâmica que caracterizavam aquela época do ciclo coletivo. À tarde, paramos um pouco - no meu caso, também para conhecer pela primeira vez - as tendas de dona Ângela, dona Maria de Lourdes, dona Marilda, dona Diva e de Alex, algumas delas situadas na José Montaury. Enquanto tomávamos um cafezinho, descansávamos para a reunião de logo mais, na sala 10 do Mercado Público, da Região Centro do Orçamento Participativo. Em meio à intensidade dos clientes e dos transeuntes, meus informantes circulavam intensamente entre as bancas cujos limites físicos não eram claros; atendiam uns as bancas dos outros, numa rede de trocas infindável e quase impossível de ser mapeada. Alguns clientes já avistavam de longe os produtos, e cabia ao camelô apenas atraí-los com gestos efusivos: a venda já estava feita. Volta e meia, meus informantes desapareciam no fundo das bancas, que já era também a fronteira com o vizinho; pediam que eu cuidasse do local por alguns instantes; alimentavam, enfim, esse deslocamento tão característico de suas movimentações no espaço público tornado, de alguma forma, particularizado. O ciclo de bebidas continuava: chimarrão, cafezinhos, alguns quitutes oferecidos pelos camelôs que transitavam. A circulação das conversas e jocosidades se intensificava cada vez mais, de modo que era impossível dar conta de etnografá-las. Decidi, ao invés disso, apenas acompanhar interagindo, ouvindo e trocando com as narrativas dos últimos dias na rua e das periculosidades que os aguardavam no camelódromo, enquanto imaginavam o seu próprio trajeto até a entrada do prédio, na Voluntários da Pátria.

- Não sei se vocês já observaram, pelos jornais e pelo rádio, a polêmica desse camelódromo. A idéia veio daqui de dentro do $\mathrm{OP}$, do Juliano. E agora ele tá sendo tomado por grandes empresários paulistas! Eles vão ficar com os melhores espaços! Eles cortaram meio metro de cada um de nós pra construir uma mega loja pros paulistas, no fundo do prédio. Quando o secretário Bulling teve no OP, ele garantiu que seria dois por dois. Tem algum paulista que vai no OP? Demandando? Eu nunca vi nenhum! Então se a coisa nasceu lá dentro, a última palavra deve sair de lá de dentro!

- Nós da ASFERAP legítimos na demanda do camelódromo, e também legitimamente estamos infelizmente entrando na justiça contra o camelódromo. A ASFERAP não vai se render à SMIC. Nós fomos traídos por esta secretaria, e nós vamos ganhar por que a justiça está do nosso lado.

A reclamação de traições tanto da SMIC como de membros da ASFERAP é notória. Fomos traídos dentro de nossa própria classe! Outras pessoas contaram também que foram mal tratadas pelos funcionários da prefeitura que teriam mandado calarem a boca, como se estivessem fazendo um favor e não sua obrigação. Eu to indo pra lá muito insatisfeita. Depois de tudo que a gente fez... (...) Somos macaquinhos adestrados da SMIC!

Algumas pessoas ainda denunciam as vendas e barganhas dos novos pontos do camelódromo, em troca de benesses ou vantagens advindas da prefeitura. Sonia Gonzáles não é mais da ASFERAP, não é delegada e não tem mais direito a nenhum espaço no camelódromo, pois virou secretária do secretário da SMIC. Traiu a ASFERAP.

- Nós estamos cansados da indefinição da prefeitura com relação ao nosso futuro! E nós precisamos trazer a SMIC pro OP o quanto antes!

- Esse estacionamento também está cheio de irregularidades, desde o seu projeto até a execução! As empreiteiras só querem tirar lucros por causa da iniciativa privada! Só que isso não vai reverter em menores custos de aluguel para nós, no camelódromo!

- Ontem nós falamos sobre o estacionamento. Porque não inaugura? Será que realmente aquele troço tá liberado pela SMOV e pelos bombeiros? Será que realmente aquilo suporta 250 carros? Será que não é por isso, será que não é isso que eles tão escondendo de nós? Eu só sei de uma coisa: é uma máfia que ta por trás daquilo tudo! Tem interesses muito grandes em jogo!

- Há boatos de que nossa obra do camelódromo está paralisada! A minha maior preocupação é porque isso mexeu com um monte de coisas e de pessoas. Nós da ASFERAP continuamos cumprindo nossos horários muito bem na rua. Ah, sobre a violência: a mídia tá metendo pau em nós mesmo. A violência que a gente observa acaba prejudicando os nossos trabalhos, o que a gente vai fazer? E quem tem o direito de poder chegar

Iluminuras, Porto Alegre, v.12, n. 28, p. 104-142, jul./dez. 2011 
e gritar e mandar nos outros como bem entende? Eu acho assim, que apesar de todas essas coisas a gente continua cumprindo com os nossos horários, e como dizia o Zagallo, 'eles vão ter que me engolir!'

- Só quem está junto pra ver e ter noção do que acontece! Eu acho que todo mundo aqui é gente, ninguém é animal! Esses dias os brigadianos correram atrás de um guri, trabalhador, até ele bater a cabeça e sangrar, depois fugiram.

- Estamos vivendo quase uma ditadura! A Brigada Militar está agindo como Polícia Civil e SMIC, com a petulância de revistar as bolsas das pessoas que chegam às bancas. Isso é abuso de autoridade!

Algumas pessoas convidaram-se a sentar e aguardar uma ação da polícia, que circulava nas imediações; de fato, não demorou e os agentes passaram em frente as bancas, dirigindo aos meus informantes um olhar enviesado, como que demarcando o espaço social que os distinguia. Um pouco adiante, uma viatura preparava-se para deixar o local, até que alguns guardas decidiram abordar um sujeito que circulava anônima e desconexamente pelas ruas: seus movimentos inusitados, a roupa esfarrapada, as gesticulações incompreensíveis faziam suscitar as suspeições em torno do que ele estivesse fazendo naquele lugar. Bastava que fizesse menção de abordar qualquer pessoa na rua para que os policiais agissem: e foi exatamente o que ocorreu. Enquanto tentava abordar desastradamente os clientes que passavam pelas ruas, foi interrompido e cercado por três brigadianos, que recolheram suas mercadorias e fizeram-no deitar-se no chão. Alguns camelôs que vieram acudir e gritar diante do ocorrido comentariam, logo depois, que o sujeito tinha sido alvo de golpes e chutes por parte dos "agentes de Estado". O evento foi motivo de inúmeros protestos e xingamentos, permitiu suscitar e acionar lembranças de outros acontecimentos semelhantes que apontariam para a desumanidade de fiscais e policiais no trato com os camelôs. Diante dessas situações cotidianas, o camelódromo subitamente era ressignificado como uma espécie de símbolo ou avatar de novos tempos, na idílica expectativa de que as inumeráveis mudanças objetivas - antes negativadas - poderiam ao menos trazer consigo o acesso à cidadanização e à dignificação subjetivas...

- Quero dizer que não são todos os que terão lugar no novo camelódromo, somente aqueles que a gente sabe que são camelôs e que a gente conhece e confia!

- Os brigadianos deram num guri que tava trabalhando saiu até sangue, espancaram mesmo. Como se não bastasse, os policiais tão falando que o camelódromo não vai sair pra nós...

Diante desse quadro perceptivo em permanente mudança, o que e como etno-grafar? É a própria mudança que interessa, a dinâmica, a ciclicidade entre a entronificação da rua, a negativização do camelódromo, o distanciamento da rua, a afeição pelo camelódromo... É a "afetação", discursiva, emocional e corporal, que está em jogo, enquanto se espera pela definição de uma identidade em permanente fluxo entre o estranhamento e a familiarização. Entre os conflitos e as incertezas de apropriar-se do espaço ou de debandar dele, entre movimentos que buscam a rua ou a legalidade, há todo um acumulado de fragmentos, de dados, de fatos, que permitem que essas narrativas sejam formuladas: trata-se de uma "natureza" tornada discurso, memória e prática, de acontecimentos traduzidos e narrativizados, de uma discursividade prenhe de sentimentos e percepções. Se os órgãos midiáticos constituem a sua argumentação - e reputação - em torno da construção dos fatos, tais como a propulsão de "denúncias" de "irregularidades" na distribuição das bancas ou de irregularidades na infra-estrutura do prédio, é fundamentalmente a reapropriação delas a favor de uma tradução em termos das inseguranças ontológicas e subjetivas dos sujeitos afetados que realmente importa nessas narrativas citadas. Não é que a fiscalização das condições de construção do estacionamento do camelódromo, por exemplo, não seja relevante para esses 
sujeitos, mas, antes, que não se trata de uma preocupação propriamente técnica com relação às condições do espaço, mas de uma apropriação estratégica e subjetiva desses "problemas" constituídos a partir de frentes discursivas que envolvem, como vimos, sobretudo a mídia retraduzidos para o léxico local que caracteriza a dinâmica da transição, do jogo de fronteiras entre o informal e o legal.

A maturação imagética da materialização, lenta e gradativa, de uma experiência de transição, permitiu entrever e projetar, como que por uma espécie de antevisão, o malfadado "destino" que estaria reservado aos novos lojistas a partir dos encargos decorrentes do processo de legalização demandado pelo poder público. Inúmeras e exaustivas comparações desse tempo concomitantemente futuro (pois que encerrava um devir, um inesperado reservado) e passado (pois que permitia ser antevisto, suas conseqüências já podendo ser de alguma forma prefiguradas) com a experiência vivida da rua estava por instituir, portanto, as fronteiras de um novo espaço-tempo a partir do qual os acontecimentos pregressos seriam recolocados em novos quadros de narração, sua semântica esvaindo-se e consubstanciando novos argumentos para a elaboração da transição. Uma nova imagem da rua estava em processo de lapidação, uma rua que pudesse fazer frente ao "destino" simbólico que inelutavelmente os aguardava e a partir de cuja perspectiva as piores agruras do tempo vivido (as intempéries da natureza, as incertezas das vendas de oportunidade, etc) eram mais desejáveis que o mais tênue sinal desse novo horizonte que estava por ser desenhado, ou melhor, que redesenharia a própria imagem perceptiva e subjetiva desse horizonte, desse sujeito que imagina e projeta.

O debate travado naquele momento inseria-se, portanto, num quadro mais amplo acerca das diversas postergações com relação à inauguração do prédio sugeridas pela intervenção dos movimentos sociais e homologadas (traduzidas), pelo governo municipal, nos termos jurídicos apropriados à caracterização do atraso nas obras (tais como a interdição do prédio em função de problemas infra-estruturais, da estipulação de critérios relativos à segurança, ou ainda de irregularidades decorrentes do processo de licitação e de físcalização da obra). De outra parte, igualmente, as estratégias de postergação significavam uma alternativa de resistência ao futuro incerto e imprevisível projetado pelo sentido do jogo incorporado dos camelôs afetados, materializada, por sua vez, na criação de figuras e narrações mitopráticas de periculosidades que operam como signos e depositórios materiais de expropriação ou extravasamento dos sentimentos e emoções associadas e acionadas pelo 
processo de transposição física e cultural da rua para a "gaiola", como fazem questão de ressalvar.

Após uma série de negociações e intervenções estatais, de vigas que subitamente apresentavam rachaduras, de incompletudes na estrutura de segurança, de lapsos na sinalização do prédio, de modificações de última hora nos dispositivos de prevenção a incêndios - enfim, desse conjunto de elementos pré-figurados que permitiram a elaboração nativa de uma série de narrativas metonímicas e metafóricas, de lendas urbanas catastróficas sobre a destruição prematura do prédio com a conseqüente morte dos comerciantes populares -, o complexo foi aberto à população no dia 9 de fevereiro de 2009, segunda-feira, e a proibição do comércio informal nas vias públicas, declarada e notificada oficialmente às nove horas da manhã do mesmo dia.

De um lado, do ponto de vista simbólico, como vimos, essas narrativas catastróficas, de fato, não fazem outra coisa que dramatizar, por homologia, o "destino", imaginado por esses comerciantes populares, de seu próprio processo de transição diante de uma conversão ao projeto de self proposto pelo Camelódromo, impossível de ser concebido integralmente. Dessa perspectiva, resistir-se-ia com todas as "fissuras" da transposição, enquanto fosse possível (por homologia à série de postergações da inauguração do prédio, em decorrência de "fissuras" e "rachaduras" no prédio que abalaram a sua segurança), até que o despejo se tornasse o fim inevitável (por homologia à morte dos comerciantes através da sucumbência da infra-estrutura diante de todas as irregularidades apresentadas).

De outro lado, do ponto de vista político, essas narrativas sinalizam um ponto de ruptura nas condições objetivas experimentadas pela transição. Como os meios de comunicação fizeram questão de (re)afirmar, o ritual de passagem implícito na abertura do novo prédio traz consigo, também, a suspensão e o sanção de multas relativas ao comércio informal nas ruas do centro (de cerca de R\$ 1200, de acordo com o secretário municipal, aplicáveis a qualquer ambulante irregular, seja nas ruas, seja no Camelódromo), isto é, de um corpo jurídico que deverá, doravante, ser observado e aplicado por intermédio dos fiscais estatais, encarregados de fazer cumprir os desígnios da lei, auxiliados pela Brigada Militar na tarefa de execução, e pelos administradores da empresa que detém a concessão do espaço, para a fiscalização dos novos comerciantes, do cumprimento da nova rotina (traduzida na pontualidade, assiduidade, na comercialização de produtos legalizados e autorizados pelo Estado, etc.). 
28 de janeiro de 2009. Cheguei ao camelódromo pouco antes das $19 \mathrm{~h}$ desta última quarta-feira do mês, a fim de visualizar o que estava ocorrendo até o momento com a implantação do camelódromo. De imediato, ao entrar, verifiquei que uma grande quantidade de bancas, para não dizer a expressiva maioria delas, encontrava-se cerrada e sem qualquer vestígio de ocupação; é bem verdade que poderiam estar preparadas ou organizadas, mas não havia qualquer vestígio externo, tal como placas de propaganda da loja ou sinais de alteração da configuração original estabelecida pelo projeto da prefeitura. Alguns poucos boxes estavam abertos e havia pessoas trabalhando na personalização do espaço. Entre elas, encontro Giza, uma de minhas informantes, logo na entrada, pela escada lateral, que havia decorado com cuidado e dedicação cada pedaço do novo local; na parede interna se viam ornamentos detalhadamente escolhidos; no chão, azulejos davam um toque de especialidade. No alto, a identificação: uma bela placa de cerca de um metro de largura, estampada com sua foto na metade esquerda e com os dizeres do nome de sua nova "loja" ("Cantinho do Nordeste"), tudo muito bem ilustrado com uma foto que fazia as vezes de pano de fundo, provavelmente de algum ponto turístico do Nordeste.

Giza conversava entretidamente com seu "eletricista de confiança", de modo que pediu que eu desse uma volta para conhecer todo o Camelódromo. Então fui caminhando vagarosamente até o fim da primeira metade do prédio. Observei que, entre outras coisas, à medida que me encaminhava ao fundo da construção, o tamanho dos boxes tendia a diminuir. Tinham dimensões que ficavam, notadamente, em torno de $1,5 \mathrm{~m}$ a $1,8 \mathrm{~m}$ de largura, provavelmente o mesmo poder-se-ia dizer da profundidade. Algumas poucas lojas ocupavam dois boxes seguidos, o que era perceptível por meio da placa identificadora que cortava de ponta a ponta os dois blocos. Ao fim da primeira metade, estou diante da passarela que passa sobre a avenida Julho de Castilhos, onde é possível ter uma visão bastante privilegiada dessa região da cidade, bem como se assentar em alguns dos bancos disponibilizados ao longo de sua extensão. Fica evidente, quando se observa a parte frontal do Camelódromo, que esta claramente está destinada a empresários de maior porte, uma vez que as dimensões dos boxes contrastam veementemente com as dos primeiros observados lá atrás, assim como a quantidade de locais já ocupados, entre os quais inclusive alguns já abertos ao público. O que impressiona, igualmente, é o caráter da praça de alimentação, cujos estabelecimentos já estão a funcionar em sua quase totalidade; à maneira dos shoppings, os locais são grandes, vistosos 
e, acima de tudo, gerenciados por empresas, conflitando, portanto, com os interesses iniciais de Juliano e seus pares de um "Camelódromo para os camelôs". Por toda a parte, ornamentando o local, quase como um agouro das contradições e disputas que envolvem a consolidação desse empreendimento, os sinais de indicação e as placas de sinalização contam com o símbolo e as cores da empresa "Coca-Cola" - inclusive com direito a garrafinhas sinalizadoras, que indicam a direção para onde se dirigir.

Retornei até a banca de Giza na seqüência. Ela ainda conversava com seu "eletricista de confiança", que tinha feito os últimos ajustes elétricos e telefônicos em seu Box. Mostrouse muito contente com a minha presença, de imediato perguntando-me o que tinha achado de sua arrumação. Respondi que achei muito criativo e interessante o que tinha feito; Giza já tinha trancado seu Box, pois já passava das $19 \mathrm{~h}$ e cumpria que fosse até sua "outra" loja ${ }^{13}$, na Esquina Democrática, vender seus produtos. Ela me acompanhou até o Mercado Público, e fomos conversando no caminho. Inicialmente, saímos pelo "coração" do Camelódromo, isto é, o local, bem ao centro, em que se encontram assentados em uma mesa representantes comerciais e logísticos com quem podem ser encomendadas faixas, cartazes ou placas para sua loja. Pelo que percebi, também está assentado um representante da prefeitura para os devidos cadastramentos e registros legais. Logo em frente, há uma grande escada de acesso aos terminais de ônibus, localizados no subsolo do prédio. Lá, também, encontramos alguns verdureiros e fruteiros já instalados em suas novas banquinhas cujos resquícios de tinta fresca ainda era possível sentir. As dificuldades encontradas pelos motoristas de ônibus ao fazerem a conversão para os terminais do Camelódromo também são perceptíveis; há todo um cuidado, inclusive da parte de transeuntes e pedestres, ao circularem pelas novas vias e pelas novas dependências instauradas no entorno do centro.

Enquanto caminhávamos, Giza me contou de seus projetos futuros. Disse sentir muita "peninha" de seu mais novo colega de trabalho no Camelódromo, vizinho de Box, pois percebia que seus recursos de investimento no novo local eram bastante limitados. Giza percebia tais aspectos através dos materiais que utilizava, das placas confeccionadas artesanalmente, em casa, ao invés de procurar auxílio especializado; imediatamente, raciocinou o que isto poderia significar e repercutir em termos de projetos particulares:

\footnotetext{
${ }^{13}$ Refiro-me ao seu ponto de comércio nas ruas da cidade, ultimamente um dos mais requintados e ornamentados, com direito até a telhado improvisado, manequins e expositores de roupas, situado em plena Esquina Democrática, um dos pontos de maior fluxo, na esquina entre a rua dos Andradas e a Borges de Medeiros.
} 
Eu já to pensando em futuramente comprar ou oferecer uma boa quantia para ele pela banquinha, aí eu vou poder ter uma banca dupla, conjugada! (...) Eu também poderia conseguir uma banca em qualquer outro lugar aqui do Camelódromo, tem muita gente oferecendo, ia ser fácil, mas aí fica difícil ter duas lojas separadas...

Giza também contou das atribulações e indefinições em torno da escolha do nome de seu estabelecimento.

Ah, eu resolvi colocar aquela foto minha, ta meio apagada e pixelada, mas eu achei que assim seria melhor, é só pras pessoas terem uma idéia, sabe. Essa foto é de dois anos atrás, minha clientela é toda daquela época, todos me conhecem com o cabelo solto, mas hoje eu ando só de boné (...). Eu pensei no início em usar 'Cantinho da Giza', porque todo mundo me conhece assim, mas aí eu fui vendo que as pessoas tavam usando 'cantinho desse um', 'cantinho daquele outro', aí eu vi que iam pensar que eu taria copiando eles... Então eu lembrei que as pessoas me chamam de nordestina, de baiana, por mais que eu seja pernambucana e não goste de ser chamada de baiana, aí então eu pensei que poderia usar 'Cantinho do Nordeste' 14 .

$$
* * *
$$

05 de fevereiro de 2009. Quando encontrei, na última quarta-feira, momentos antes da reunião do FROP Centro, Dona Vera, esta nos confessou empolgada os últimos preparativos para a tão alardeada abertura do Camelódromo. Orgulhosa, pronunciou que já havia gasto mais de $\mathrm{R} \$ 5$ mil reais em investimentos no novo espaço, e convidou-me para vir conhecer seus estandes. Aceitei o convite, e anotei os telefones de Dona Vera para entrar em contato e agendar a visita nos próximos dias. Encerrada a reunião, conversei novamente com ela, Seu Zé e mais alguns membros da ASFERAP, que propuseram que viéssemos hoje mesmo, dia 5, quinta-feira, para visitar os boxes e acompanharmos de perto os últimos preparativos para o início dos trabalhos, na segunda-feira. Todos estavam muito empolgados, ao mesmo tempo ansiosos pela indeterminação com relação ao futuro. O pronunciamento de Juliano, que se mostrava pouco confiante com relação à inauguração na próxima segunda-feira, trouxe novas inseguranças, uma vez que disseminou novas expectativas com relação à manifestação do Ministério Público nos próximos dias com vistas a postergar a inauguração.

- Os próximos dias vão ser decisivos pra gente saber se vai ou não vai abrir; o Juliano disse que não é bem assim para eles abrirem, que tem que primeiro cumprir todas as exigências do Ministério Público. Eu só quero ver, se a gente receber uma notificação, vamos encaminhar pra eles!

Cheguei às dependências do CPC no início da tarde de quinta-feira, um dia bastante quente e ensolarado. Resolvi que seria oportuno telefonar para Dona Vera, para que esta pudesse me encontrar em meio ao mundaréu de pequenas lojinhas que estavam por ser

\footnotetext{
${ }^{14}$ Fragmentos de diário de campo dia 29 de janeiro de 2009.
} 
instaladas. Fiquei esperando na parte frontal do prédio, cuja vista privilegiada fica de frente à rua Voluntários da Pátria. Em alguns instantes, chega Dona Vera, sorridente, para me recepcionar. Ela me conduz até onde está sua primeira banca, logo na parte frontal do Camelódromo. O espaço, segundo ela mesma, não é seu; na verdade, está sendo sublocado por outro proprietário que, ao que consta, não possui interesse ou então as condições financeiras ou motivacionais para conduzir o empreendimento. O Box é relativamente espaçoso, possui os tradicionais dois metros de largura, por dois metros de profundidade. Já está quase todo organizado. Neste ponto, Dona Vera é orgulhosa em contar que desde o início de janeiro já vem trabalhando e se organizando em função da configuração de seus boxes. "Eu fiz tudo sozinha, ninguém me ajudou! E olha que dá serviço, viu, tem que ter muita paciência e vontade mesmo!".

Desde as últimas vendas de dezembro, Dona Vera já não está mais na rua. Resolveu que aquele seria o momento de iniciar o processo de transição. Aos poucos, desde o início de janeiro, já foi encomendando os principais materiais para a personalização de seu espaço.

- Eu gastei dois mil reais e pouco só para mandar fazer a estrutura básica, as paredes e esse material especial, onde depois eu posso pendurar as mercadorias. E eu paguei a vista! Paguei a vista! Então eles me disseram que só poderiam estar entregando no fim do mês, mas eu fui uma das primeiras a receber! Eles acabaram entregando em menos de uma semana. Quando eu menos esperava, já estava aqui o pessoal pra montar tudo. Porque eles priorizam quem paga mais, quem gasta mais, e quem paga a vista! Mas também tem que ser assim! Eu sei porque a Ângela recebeu o dela só nesses últimos dias, e o meu já ta instalado faz muito tempo. Eu acho que é porque ela não pagou a vista e também porque comprou menos coisas.

Dona Vera pensou em todos os detalhes para a maximização e sofisticação do Box.

- Eu tentei usar só branco. Porque dizem que branco aumenta a sensação de espaço. Eu também coloquei essas prateleiras só lá no alto, para colocar os manequins com roupas em cima. Por enquanto não vou usar manequins grandes, porque eles estão custando na base de $R \$ 180$ a 200 reais, e para colocar a roupa infantil eu consegui fazer algo bem interessante. Quem vê se admira e tenta copiar o que eu faço! Eu coloquei as roupas de criança que eu vou ter na outra banca em bonecas, ao invés de comprar manequins caríssimos! E ficou tão bonito!

De fato, Dona Vera colocou uma única fileira de prateleiras conjugadas, formando um “U”, na parte superior do Box, para dispor os meio-manequins. A parte inferior está disposta organizadamente com uma espécie de cabide onde serão colocadas as roupas. Ao centro do Box, o espaço é livre, "para as pessoas poderem circular e entrar na minha loja". Desde os azulejos do chão, até a cor do ventilador de teto, escolhido a dedo em função do tamanho adequado, tudo está revestido na cor branco. 
Um ponto importante que Dona Vera fez questão de contar pormenorizadamente é a escolha do tecido da cortina. Sim, sua intenção é colocar, ao fundo da loja, um pequeno provador de roupas, para que os clientes interessados possam, à semelhança de lojas de maior porte, experimentar o produto antes de levá-lo. É interessante observar como a própria dinâmica e rotina de compras passa a ser concebida de um outro modo, a partir da introdução de um novo elemento intermediador da negociação, o provador.

- Quando eu fui comprar o tecido, eu coloquei os olhos nesse que eu comprei. Era tão lindo, tinha que ver! Todo branco, com detalhes estampados e desenhados brilhantes. Parecia um vestido de noiva! Eu levei para casa depois, e a minha filha disse que queria que eu fizesse um vestido pra ela com o tecido, ai eu disse, 'não, isso aqui é para a cortina do meu box'. O pior é que uma outra senhora quase levou! Eu pus os olhos, mas aí ela pegou! Ela carregou debaixo do braço pra cá e pra lá, e eu só atrás, observando e cuidando. Depois ela devolveu, porque eu acho que ela não tinha dinheiro para pagar, aí eu fui lá, agarrei com as duas mãos e não soltei mais. Mas é muito lindo o tecido, tem que ver, ele ainda não ta aqui, mas semana que vem já vai estar!

Sobre o pequeno balcão - especificamente projetado para maximizar o espaço, também -, repousava um aparelho telefônico, cuja história Dona Vera prontamente contou.

- O pessoal que está aqui dentro fazendo o marketing do Camelódromo passa várias vezes para oferecer cartões de crédito e telefones. Eu já pedi os cartões, mas eles ainda não vieram. Agora eles vão oferecer para todo mundo, porque a gente vai estar legalizado, pelo menos eu vou estar, e aí o crédito vai estar liberado. O telefone já ta funcionando normalmente. Eu comprei três linhas, uma pra essa loja daqui, a outra linha vai ficar no outro Box, lá no fundo, e a última linha vai ficar com a Nice. Ao todo isso vai custar cento e poucos reais por mês, mas a gente tem que fazer isso, para poder entrar em contato com a nossa clientela. Também não se pode pegar qualquer pessoa para fazer parceria, então tem que ser alguém de confiança, que a gente sabe que vai pagar no fim do mês, por isso foi a Nice.

Na placa de identificação, no topo da nova loja, constam os três números telefônicos, além de celulares e uma pequena foto de crianças-propaganda. No centro do cartaz, em letras garrafais, o novo nome da loja: “Troya Confecções”, em referência ao próprio sobrenome de Dona Vera. Durante toda a conversa, fiquei sentado no interior da loja, nos pequenos assentos improvisados, ou então na escadinha que servia de banco de repouso. Minha informante também contou de seus problemas cardíacos, de sua hipertensão e da insuficiência respiratória que esporadicamente a assola. Comentou que muitos de seus novos vizinhos de banca não seriam camelôs, mas pequenos empresários ou lojistas que compraram seu ponto no Camelódromo. "Esse da frente, aqui, ele não é camelô, eu nunca vi ele na rua, e tu pode ver que ele ta bem organizado, acho que deve vender por atacado também".

Na seqüência, Dona Vera me conduziu pelos corredores do Camelódromo, a fim de que pudesse conhecer as demais bancas da ASFERAP e, especialmente, a sua própria banca, 
nominalmente sua. Os estandes de nossos conhecidos, inclusive de Juliano, estão localizados nos fundos da segunda metade do prédio, nas proximidades da praça de alimentação. Pode-se observar que esta parece ser a área menos nobre de todo o local, uma vez que se situa praticamente nos "bastidores" do shopping popular e concentra visivelmente os menores boxes, em termos de área física. Assim, a diferença de cerca de meio metro de largura é o primeiro aspecto que salta aos olhos, uma vez que resulta em uma significativa diminuição do espaço interno. Por conseguinte, a demanda por criatividade para a organização dos poucos metros disponíveis exige ainda mais de cada novo "empresário", se o termo já pode ser considerado válido.

A disposição e organização deste segundo espaço se assemelha bastante ao primeiro. Já estavam colocadas e dependuradas algumas roupas infantis nos cabides afixados nas paredes laterais. Com orgulho, Dona Vera conta que consegue comercializar todo seu estoque de verão antes mesmo da estação findar, de modo que freqüentemente é compelida a confeccionar mais peças, para atender às demandas de sua clientela. Esta nova loja terá por objetivo a comercialização unicamente de peças infantis, aliando a pouca disponibilidade de espaço físico ao tamanho diminuto das roupas de criança. Dona Vera nos mostrou algumas das bonecas que usará como manequins para suas roupas de bebe, salientando novamente seu papel como autora, neste processo, da bricolagem.

- Eu to preocupada, porque aqui nessa parte é muito quente e abafado, especialmente no verão, e não tem espaço no teto para um ventilador, porque as asas vão pegar nas prateleiras, lá na outra não, cabe direitinho, tem espaço suficiente.

Como precisasse pensar em nomes concretos para estampar nos cartazes de identificação de cada loja, resolveu que seria interessante colocar o seu próprio. Assim, se a primeira banca recebeu o título de "Troya Confecções", esta última foi titulada como "Vera's Confecções". Claramente, apesar de se orgulhar em possuir e manter um Box com as dimensões originais do projeto (de $2 \mathrm{~m}$ de extensão) logo na entrada do Camelódromo, é aqui, nos espaços de trás, que prefere ficar. É aqui que estão situados seus conhecidos da ASFERAP, como, por exemplo, Nice, cuja banca se situa praticamente ao lado. Mais alguns passos, e já estamos na praça de alimentação.

- Aqui quem vai cuidar, eu já disse, é a minha filha. No início ela não queria, porque não queria. Mas depois que ela viu como ficou, ela gostou tanto e agora quer ficar aqui. Ela disse que já está parecendo uma loja, que ta tudo muito bem organizado aqui dentro. É, mas tem alguns boxes que tão mal-feitos, tem gente que não consegue investir pra fazer 
algo bonito. Na outra banca, vai ficar o meu marido; eu vou ficar circulando nas duas, mas acho que aqui vai ser o meu lugar.

$$
* * *
$$

Tão logo terminamos nossa conversa no interior do Box, apreciando as roupas confeccionadas e já adequadamente expostas de Dona Vera - que renderam vários elogios de minha parte e várias histórias de vendas contadas pela anfitriã - fomos conhecer as proximidades e seus novos ocupantes. Dobramos na "esquina", passamos uma das fileiras, e entramos no corredor, onde de imediato encontramos Dona Marilda fazendo alguns ajustes em seu Box. Além dela, havia ainda um senhor, que trabalhava junto ao balcão, fazendo os últimos ajustes com uma furadeira.

O assunto, como não poderia deixar de ser, era a banca de Juliano, que ficava logo ao lado, cuja arrumação e organização nem havia, ainda, sido iniciada.

- E o Juliano, Marilda, que nem começou ainda a organizar nada. Eu to preocupada com ele, porque ele ta muito pra baixo. Daqui a pouco a SMIC vai notificar ele como desistente e vai colocar outro no lugar dele. Tu pode ver aqui que ele ainda não fez nada!

De fato, havia somente algumas madeiras escoradas no canto da banca; de resto, tudo permanecia exatamente do mesmo modo como foi entregue pela Secretaria de Indústria e Comércio: o chão de concreto (uma extensão do chão do corredor) e as paredes separadas por pequenas grades, à semelhança de uma prisão. Dona Marilda complementa:

\footnotetext{
- Eu e a Dona Diva tivemos que passar um cadeado no Box do Juliano, porque senão ele nem estaria fechado e provavelmente a essas alturas já estaria ocupado por outra pessoa! O Juliano é muito desligado para isso, não da para colocar a chave do cadeado nas mãos dele que ele vai perder certo! A gente pode fazer até um mutirão para organizar a banca dele, porque na minha, por exemplo, sobraram vários azulejos e madeiras. Esses retalhos sempre dá para aproveitar e fazer algo bonito.
}

Dona Diva, apesar de não a encontrarmos nas dependências, também tinha sua banca nas proximidades, ao lado da de Juliano; por debaixo da grade que fechava o local, podia se observar que azulejos escuros já adornavam o chão do estande.

Encerradas as conversas com dona Marilda, que ainda permanecia em seu Box aguardando a finalização dos últimos reparos, dona Vera e eu seguimos pelos corredores do Camelódromo na direção da banca de Seu Zé, que se situava igualmente nas proximidades, mas nos corredores laterais de acesso. Logo ao chegarmos, o primeiro aspecto que chama a atenção é a enorme viga de concreto que está posicionada logo em frente ao Box, de modo a 
encobrir boa parte de sua visibilidade e, por extensão, suas chances objetivas de venda e concorrência. A viga distancia-se em cerca de meio metro em relação ao balcão do Box, de modo que neste intervalo há espaço para somente uma pessoa. Seu Zé se consola:

- Tem gente que teve que conviver com uma viga dessas dentro da própria loja! Não sei, parece que eles deram um desconto no aluguel, mas vai saber né... E sempre tem esse incômodo aí dentro daí. Eu to bem aqui, acho que não vai me incomodar muito não...

De lá, saímos corredores afora para conhecer o restante das bancas. Dona Vera puxava a caminhada, observando com cuidado o acabamento de cada Box. Como a maioria estivesse fechada, ela buscava com algum esmero observar por entre as frestas disponíveis quais os materiais que haviam sido utilizados, bem como a disposição dos móveis e das mercadorias. A distribuição criativa dos produtos, aliada à qualidade dos materiais empregados, denotava o nível de engajamento de cada novo empreendedor para com o projeto do futuro comércio, uma vez que fazia menção, para Vera, ao tempo dedicado à criação de seu projeto individual personalizado de negócio. A criatividade, ou melhor, a inventividade, a bricolagem, portanto, se é que tais termos fazem algum sentido nesses contextos, parecem constituir-se num aspecto central da argumentação daqueles que, desde cedo, se mostram dispostos e afeitos à mudança cultural e social desencadeada pelo projeto de legalização do trabalho informal e, por extensão, da transfiguração da categoria "Camelô".

Quando chegamos às proximidades do corredor de ligação sobre a Avenida Júlio de Castilhos, Dona Vera me convidou para tomarmos um cafezinho. Aceitei o convite, de início um pouco constrangido pela insistência de sua parte em arcar com as despesas financeiras da conversa. Enquanto permanecíamos em uma das mesinhas de mármore afixadas permanentemente no corredor de vidro, Dona Vera me contou algumas fofocas, à medida que passavam pessoas que conhecia. Uma delas, a história notadamente mais extensa e marcante para ela, tratou de uma mulher que havia hospedado há algum tempo e que não havia correspondido às suas expectativas de reciprocidade.

\footnotetext{
- Era uma pessoa aparentemente simples, tinha um filho que era cego, e ela precisava muito de um lugar para ficar por uns tempos... Então eu ofereci um canto pra ela e o filho na minha casa, no meu apartamento que é bastante espaçoso, tem lugar para duas famílias. Isso até ela se ajeitar na vida, conseguir um emprego, fazer alguma coisa. Mas não deu certo, porque eles não souberam valorizar. A criança não sei o que tinha, que quebrava tudo, não podia deixar nada de pé. Eles chegaram a rachar uma das minhas portas! Aí eu já não dava mais, ela estava ficando muito abusada! Até que eu tive que dizer
} 
para elas arrumarem as coisas, que eu já não podia deixar eles ficarem lá. Meu marido tem problemas cardíacos, e eles faziam muita bagunça, era um inferno!

Longe de constituir-se numa história supérflua no contexto da transição, ela opera como um ponto de apoio sobre o qual as memórias desse novo espaço são constituídas e adquirem sentido. É, portanto, a esses outros espaços que as experiências do camelódromo conduzem dona Vera, seja evocando experiências pregressas na definição do presente, seja definindo o passado em função das novas percepções engendradas no presente. De modo que, para além da "fofoca", a narrativa dramatiza um certo senso de reciprocidade transfigurado para o contexto do próprio camelódromo: assim como os investimentos - sejam eles subjetivos ou objetivos - à espera de correspondência no caso da mulher que havia hospedado, dona Vera performatiza em seu discurso também as esperanças de reciprocidade acumuladas e materializadas nos próprios dispêndios e esforços colocados na concretização da passagem ao projeto do camelódromo.

Depois do cafezinho, voltamos para onde está localizada a banca de Dona Marilda, seguidos pelos focos de conflito e de fofoca, onde encontramos uma senhora desiludida com o novo projeto do Camelódromo.

\footnotetext{
- Olha, isso aqui não vai dar certo! Eu to aqui cuidando a banca, eu fiz associação com uma outra mulher que me apareceu hoje com essa placa com as fotos das filhas dela! Eu digo, o que é que é isso! Eu que to pagando o aluguel dessa joça, a banca é minha! Ela só entrou para ajudar a fazer alguma coisa, e agora aparece com essa placa com a filha e a neta estampada! Eu vou tirar isso daí! Ou colocar outra por cima! E olha o nome da loja que ela colocou... 'Van der Marri'! E eu nem me chamo Marri! Meu nome é Maria! O nome dela ta lá, mas e cadê o meu?! Olha, eu vou te contar...
}

Dona Vera e suas conhecidas indagavam a estranha sobre os motivos que a levaram a fazer uma aliança com tal pessoa, mas a resposta, vaga e titubeante, deixou nas entrelinhas que prováveis acordos familiares, tácitos, estavam ordenando a formação dessa parceria.

\footnotetext{
- Para completar, ela ainda me coloca essa frase que eu detesto... 'Jesus te ama'! O que é isso! Eu nem religiosa sou, não acredito nessas coisas! (...) Aqui dentro a gente vai falir! Todo mundo vai pro saco!
}

Este parecia ser o tom das últimas conversas de que participei no dia. Quem apareceu, ainda, para visitar o Camelódromo, foi Lindomar, assistente de Juliano durante a campanha eleitoral de 2008 e um de meus informantes mais prolixos e esclarecidos. "Voltei de viagem essa semana, estava curtindo as férias... A minha mãe tem banca aqui, então eu resolvi vir 
aqui visitar ela e ver como está a obra”. A banca de sua mãe estava logo ao lado da de Marilda e Dona Diva, e foi ali que a maior parte do diálogo se passou. Bastante desconfiada, apreensiva e pessimista quanto ao futuro desses novos empreendimentos no Camelódromo, afirmou:

\begin{abstract}
- Isso aqui é um negócio sem volta, que eles fizeram já pensando no nosso extermínio, no nosso fim! Eles conseguiram nos trazer amarrados pra cá, e agora eles tão vendo que nós não temos a mínima chance de ficar aqui dentro, que ninguém está vendendo nada, que não vai dar certo, depois eles vão dizer, 'ah, a culpa foi deles que não se prepararam e não souberam vender o seu peixe, porque nós providenciamos um lugar bom para isso', e vão lavar as mãos quando tudo isso aqui acabar!
\end{abstract}

Lindomar assente com a cabeça, concordando com o argumento da mãe e acrescentando que "isso aí o Juliano já dizia há muito tempo, desde que essa história de Camelódromo está circulando!"”.

- Eles tão querendo acabar com o camelô, querendo limpar e varrer o centro, daqui a algum tempo, quando esse prédio não tiver mais servindo aos interesses deles, eles também vão desocupar aqui e tudo isso que vocês estão fazendo, se esforçando pra dar certo, não vai ter servido de nada!

\title{
AS ESTRATÉGIAS DE APROPRIAÇÃO E SEMANTIZAÇÃO DO TEMPO E DO ESPAÇO
}

O deslocamento até o camelódromo implica, sobretudo, uma caminhada epistemológica, uma dinamicidade, uma movimentação que faz referência a pelo menos duas dimensões complementares: ao mesmo tempo em que inaugura um trajeto espacializado, isto é, um percurso objetivamente delineado no seio da paisagem constitutiva da região centro da cidade, ele é, também, e antes de tudo, um movimento narrativo, ou seja, construtor de uma certa temporalidade em deslocamento. Do ponto de vista do antropólogo em campo, problematizar o movimento implica, seguramente, considerar o seu próprio itinerário a partir desta dupla semântica: de um lado, o movimento que o etnógrafo realiza junto com a alteridade, descobrindo o espaço no acompanhamento dos trajetos objetivos por entre corredores e paredes do camelódromo; por outro lado, as manobras que o antropólogo realiza para "colocar a alteridade em movimento", procurando suscitar e acompanhar os deslocamentos espaciais e físicos que a própria narrativa desse indivíduo sugere.

As narrativas acerca da dinâmica da transição colocam em jogo, de um lado, o problema do "tratamento" e, por extensão, da qualidade das relações com as instituições que fundamentam a perspectiva de legalização subjacente ao projeto de camelódromo. Se os 
procedimentos jurídicos-formais de visibilização da mão-de-obra informal se colocam como inevitáveis, do ponto de vista da construção desses sujeitos, então nada mais legítimo do que fazer valer a perspectiva do cidadão demandante de direitos, amparado por sua vez, entre outras coisas, na manipulação da cultura escrita, através do documento que autoriza, legalmente, a ocupação contratual dos boxes. Nesse sentido, a ambivalência no tratamento por parte dos agentes encarregados da fiscalização - através do emprego de técnicas ou dispositivos de promoção da violência física, estética e moral que fazem menção àquelas utilizadas na rua, quando eram consideradas legítimas - implica o não reconhecimento das novas condições inauguradas com a abertura das lojas.

Por outro lado, essa positivação da legalidade esbarra, a todo o momento, no cumprimento e na incorporação dos "ônus" da mudança; se o Estado é rechaçado ao tratá-los com a ambigüidade característica da transição entre a informalidade e a legalidade, não é menos reprovado por instituir precisamente os critérios de ocupação e visibilização das fronteiras do que é estar no camelódromo. As "vantagens" advindas da instrumentalização, do papel assinado, do alvará em dia, são assim obliteradas pelas preocupações em fazer cumprir o pagamento das novas taxas financeiras: alugueis semanais, serviços de condomínio, contas de luz, telefone, internet e cartões de crédito, despesas com a manutenção da infra-estrutura dos espaços e das mercadorias, etc. Somam-se a isso as tentativas de consolidação do esquadrinhamento do tempo e do espaço, através da instauração de prazos e horários rigidamente afixados e horizontalmente individualizados; de espaços de comercialização que exigem a maximização funcional de sua arquitetura interna, a distribuição equânime de pessoas e objetos, enfim, a padronização externa das diferenças em favor da diversificação interna da organização do espaço.

De certa forma, é o "mundo" da rua que é preciso traduzir e insuflar para dentro da banca de cerca de quatro metros quadrados; é no âmbito da banca que doravante deverão ocorrer as competições de diferenciação de objetos, técnicas e pessoas, não mais na apropriação do espaço externo. Aqui, o corredor é projetado para a "livre circulação": na rua, era o próprio corredor, através das calçadas, que importava apropriar e se constituía no cenário das disputas pela diferenciação estética da comercialização de produtos que, em sua essência, eram semelhantes. É, portanto, uma homologia semântica que se pretende atingir entre as posições simbólicas ocupadas por cada agente nesses campos tão clivados quanto a amplitude da distância social que separa a rua do camelódromo. 
A dinâmica da transição traz consigo o problema da constituição das fronteiras identitárias desses sujeitos em pleno processo de reelaboração de sua subjetividade. De modo que a espessura simbólica desse trajeto de deslocamento implica um constante tensionamento em relação às figuras liminares que compõem a paisagem do novo espaço de trabalho, tais como os agentes de fiscalização, os representantes do Estado, os administradores da empresa, os próprios “comerciantes populares" (em sua diversidade biográfica e de engajamentos), bem como os novos e antigos camelôs que permaneceram na rua ou na "lista de espera", e que paulatinamente retornam aos seus antigos pontos nas calçadas das ruas do centro e nas escadarias de acesso ao camelódromo. A dinâmica da legalidade não exclui diferentes estratégias de aproximação ou afastamento de cada um desses vários posicionamentos e universos de pertencimento social; ao contrário, o que a própria trajetória de Juliano parece indicar é um flerte com o universo moderno-racional do cidadão de direitos ao nível da mobilização pública e da politização dos símbolos da transição, ao mesmo tempo em que, do ponto de vista subjetivo e das estratégias de produção do sujeito comerciante, permanecem certas táticas referenciadas ao universo da rua, e a incorporação de tantas outras que sinalizam a ambigüidade constitutiva da transição. Tal é o caso, por exemplo, da incorporação de mercadorias "pirateadas" ao leque de possibilidades de comercialização, ao mesmo tempo em que, da perspectiva da construção identitária, preconiza-se um afastamento em relação aos camelôs que permanecem na rua e que, doravante, com a construção do camelódromo, deverão ser, por excelência, o alvo dos agentes de fiscalização da SMIC. Neste caso, o que os diferencia não são as práticas e saberes que orientam as estratégias de comércio e a seleção das mercadorias - já que entre ambos os casos há somente uma diferença de grau e não de natureza - mas, sobretudo, a forma como os estabelecidos nos espaços do camelódromo postulam e constroem suas especificidades identitárias, legais e posicionais, em oposição ao camelô ordinário que nem ao menos possui qualquer papel homologado pelo Estado que lhe assegure o direito ao livre comércio.

Com efeito, os "cavalos", como são chamados os camelôs que se situam em frente à escadaria principal do camelódromo, oferecem, em sua maioria, CDs, DVDs e calçados piratas, ao passo em que os "novos comerciantes populares" tendem a se especializar no comércio de determinados setores de mercadorias, tais como confecções de marcas falsificadas, eletrônicos vindos do Paraguai, entre outros produtos. Ao mesmo tempo, as estratégias de abordagem de clientes fazem lembrar o universo da rua, ao colocar como 
central o papel do vendedor na instituição da relação de reciprocidade econômica: uma das características estéticas da dinâmica do comércio informal, sobretudo nas calçadas e ruas do centro, está em que não se espera passivamente a iniciativa do transeunte em demonstrar o interesse em um determinado produto; é ao vendedor que cabe oferecê-lo constantemente ao cliente, por meio do emprego de estratégias performáticas, seja de locuções adjetivadas e gritadas, seja através da movimentação pelo espaço que lhe é destinado, observando o perfil dos transeuntes e procurando estabelecer nexos hipotéticos entre o que se espera seja o seu perfil de consumidor. Muitas dessas táticas podem incluir, de fato, a interação corpo a corpo, a movimentação de braços e mãos do vendedor buscando atingir seu potencial cliente, ou ainda o tratamento pessoalizado ao dirigir-se, de longe, ao indivíduo que passa em frente a sua banca. Nesse sentido, passar pela escadaria de acesso constitui-se realmente numa espécie de rito de passagem desafiador, já que é preciso, num primeiro momento, despistar ou desfazer-se dessas estratégias de vendagem empregadas pelos "cavalos" que, não raro, acompanham insistentemente o potencial cliente até o fim do lance de escadas, dirigindo-lhe sugestões pessoais ou então oferecendo modelos de calçados e títulos de DVDs ou CDs.

Certa feita, enquanto caminhava pela saída do camelódromo, uma senhora que me acompanhava relatou-me: "Se for assim, eu digo pro Cecchim que eu vou colocar 10 cavalos para fazerem divulgação da minha lojinha e levar os clientes pra lá. E digo também que eu vou vender meias do Paraguai, sim! Porque se não for assim, não tem como vender três por cinco reais! Se a gente tem que enfrentar o monte de intermediários não da pra gente ter um preço competitivo". Esse ponto de vista justifica boa parte das tensões e insatisfações proferidas por esses comerciantes populares em relação ao tratamento recebido dos agentes de fiscalização do estado - para quem tal diferenciação, muito mais simbólica que efetiva, não se transfigura em práticas suficientemente reconhecedoras de suas novas condições jurídicas.

Ser comerciante popular significa para esses indivíduos acessar a categoria e o léxico definidor do cidadão de direitos - o que implica autonomia legal e moral diante do Estado na busca de seus objetivos particulares, entre os quais estão as escolhas das táticas de comercialização e dos produtos vendidos. Desse ponto de vista, portanto, a inevitável produção de dignidade que veio junto com a instituição do projeto de camelódromo implica considerar a transição como uma escolha mais ou menos espontânea por parte dos indivíduos afetados pelo processo, diante das vantagens claras oferecidas pela legalidade. Por outro lado, ser cidadão implica também, para estes indivíduos, a possibilidade de reivindicar os direitos 
constitucionais mais fundamentais, que são, então, apresentados como responsabilidade do Estado. Dessa perspectiva, a relação Estado / sociedade civil aparece fundamentada a partir da lógica do patronato, como uma espécie de clientelismo corporado assimétrico (Landé, 1977) em que é obrigação do Estado - essa instituição onipotente e onisciente totalizadora - prover a proteção e o sustento de seus membros, particularmente daqueles que historicamente foram alijados do processo de participação democrática e que agora demandam políticas de reconhecimento diferenciadas a partir da concepção de um Estado multicultural.

Dentro desse universo heteróclito são extraídas as ferramentas que constituirão, por mecanismos de bricolagem, a própria identidade e especificidade existencial e discursiva de meus informantes - um grupo particular no interior desse campo de forças. Essas idiossincrasias são, nesse sentido, imanentes à própria dinâmica da correlação de forças entre as posições diferenciadas ocupadas por cada um desses agentes em campo - e não são, de forma alguma, cristalizadas ou essencializadas como a categoria "identidade" pode eventualmente sugerir. No seio desses tensionamentos e deslocamentos simbólicos, corre-se o risco sempre presente de tomar como características particulares relativas à constituição de um determinado pertencimento de grupo aquilo que, por vezes, é apenas a discursividade ou narrativização contingente e situacional de um dado sujeito em meio a esse universo e mergulhado num contexto particular de enunciação diante de determinado receptor, cujo conjunto de variáveis e influentes, tão heteróclito quanto possa ser, parece a todo o momento escapar a qualquer tentativa de definição que pressuponha certa categorização homogeneizadora. Contudo, é possível identificar ao menos dois elementos significativos que orientam e presidem a operacionalização dessa transição subjetiva, do ponto de vista de meus informantes-chave.

Em primeiro lugar, há o que poderia ser nominado, muito adequadamente, a lógica local do princípio da reciprocidade subjacente ao comércio informal, a partir do qual parece lícito a esse sujeito operar nos marcos simbólicos da troca de certos favores que pressupõem, antes de tudo, uma relação diádica não-estruturada entre indivíduos ou grupos desiguais e desigualmente situados na hierarquia e tipologia dos objetos possíveis de intercâmbio ${ }^{15}$. Isso

\footnotetext{
${ }^{15}$ Não deixa de ser curioso como essa lógica está presente em todos os momentos do trabalho de campo, inclusive na relação de certos informantes com o antropólogo. Recordo, por exemplo, uma conversa que tive com seu Zé, em que este me propunha fazer uma espécie de documentário global da história do camelódromo, desde a época da rua até a transposição, de modo a poder comercializá-lo, em seguida, entre os próprios camelôs: "Então eu acho que deveria ser feito alguma coisa nesse sentido, pra preservar a história dessas pessoas, gravar o
} 
significa, fundamentalmente, de um lado, que os comerciantes populares concordam em realizar o processo de transição nos limites demarcados pelo projeto estatal de camelódromo, aceitando as implicações subjetivas e materiais desse processo e concordando com os efeitos políticos indiretos gerados pelo sucesso do empreendimento para os gestores municipais. Por outro lado, caberia ao Estado, em troca da lealdade desses "súditos", propiciar as condições necessárias à transposição e implementação do novo projeto, no sentido de minorar os impactos subjetivos e fornecer e distribuir os instrumentos - diferenciadamente de acordo com os ritmos e biografias subjetivas de cada um desses indivíduos - que possibilitem aos comerciantes sua reprodução sustentável no novo espaço. É, pois, essa lógica que explica boa parte dos posicionamentos e discursos que fazem ressaltar os sentimentos de exploração e de subserviência gerados pela discussão unilateral do projeto; é também ela que autoriza romper com a reciprocidade ao instituir como prática legítima a inadimplência - apontada como "política" por agentes de governo - como estratégia de resistência subjetiva e consubstanciação material do senso de expropriação e alijamento do processo decisório.

Em segundo lugar, isso sugere que, de um ponto de vista êmico, qualquer tentativa de desconectar os processos políticos de acionamento e canalização dessas reivindicações e insatisfações para a esfera pública, convocando o Estado para atuar como mediador, das práticas comerciais locais, da produção, invenção e reprodução desse novo sujeito que resulta do próprio processo global de transposição e narração, em palavras e coisa, desse trajeto, está fadada ao fracasso. Os limites simbólicos a partir dos quais é readequada e semantizada essa nova identidade - seja em termos de pertencimento grupal, seja a partir da gestão de um novo indivíduo tendo em vista o modelo ocidental da noção de pessoa - nunca são claramente estabelecidos e se constituem na própria dinamicidade com que tensões, aproximações e distanciamentos são negociados entre Estado, empresa e diferentes grupos de camelôs em permanente disputa.

Se, portanto, na esfera de bastidores relativa à constituição do sujeito econômico do camelódromo, observa-se, ao longo de 2009, algumas modificações tácitas e tímidas em termos de estratégias de apresentação dos produtos e de distribuição e composição do "mix"

que elas tem pra dizer, porque depois que elas morrerem, não vai mais adiantar, aí se foi pra sempre. E o seguinte: tu podia fazer isso, tu que tem essa câmera pra filmar, e ta gravando algumas reuniões, tu podia filmar isso daí, fazer um vídeo e depois vender as cópias aqui! Isso aí é uma coisa que todo mundo quer ter, todo mundo ia comprar de ti isso aí, tem que pensar nisso também. Tem que ficar esperto pra esse tipo de coisas! Fazer algum dinheiro! Tu pega esses DVDs a um pila e vende a dois, ou três, todo mundo ia comprar por esse preço! E tu ia tirar um bom dinheiro!". 
de mercadorias - talvez no sentido de uma certa especialização setorial de determinadas modalidades de bens - há, por outro lado, uma acirrada problematização nos espaços públicos de discussão que debatem disputadamente as razões dos insucessos de parte dos comerciantes populares diante de outros, mais afortunados e predispostos à concorrência e à sobrevivência mercadológica. Nessas ocasiões, o mesmo comerciante que opera à reinvenção de sua subjetividade e das técnicas e artes de fazer relativas ao comércio informal, é investido de uma outra postura subjetiva e discursiva ante os agentes de Estado, diante dos quais é preciso dramatizar determinadas técnicas narrativas e performáticas que visem à desresponsabilização do sujeito em dificuldades financeiras no camelódromo, de modo a fazer ressaltar a dimensão assimétrica da relação mantida com o Estado e, por extensão, do sentimento de expropriação e exploração subjetiva desses sujeitos a partir da consagração de um projeto que não teria passado pela discussão democrática de seus critérios de implementação. É a partir da discussão e da intervenção de Juliano enquanto mediador político nos espaços públicos, sobretudo no acionamento da Câmara de Vereadores, que a formulação de discursos de insatisfação que confrontem diretamente a lógica local da reciprocidade com as práticas de gestão adotadas pelo Estado - e, com ele, de um modelo específico de cidadão "comerciante popular" - se tornam pensáveis por parte da comunidade. Mais uma vez: é a partir dessas disputas que o próprio sentido desse pertencimento coletivo e identitário, de seus hiatos e lapsos em termos dos indivíduos que compõem essa rede, de suas particularidades biográficas e identitárias, é desenhado e trabalhado, num processo constante de bricolagem artesanal no campo indestrinçavelmente associado da subjetividade, da economia e da política.

\section{Referências}

ARANTES, Antonio. Paisagens paulistanas. São Paulo: Unicamp e Imprensa Oficial, 2000. p. 17 a 23.

BACHELARD, Gastón. La poétique de l'espace. Paris: PUF, 1987.

BAKHTIN, Mikhail. "Introdução - a apresentação do problema". In: A cultura popular na Idade Média e no Renascimento. $2^{\mathrm{a}}$ Ed. São Paulo/Brasília, Hucitec/Ed. UnB, 1993. p. 1-50.

BERGER P. e LUCKMANN, T. A construção social da realidade. Petrópolis: Vozes, 1983. BOSI, Ecléa. Memória e sociedade. Lembranças de velhos. São Paulo: Queiroz Ed. Ltda. e EDUSP, 1987.

BOURDIEU, Pierre. "O habitus e o espaço dos estilos de vida". In: A Distinção - crítica social do julgamento. São Paulo: EDUSP, 2007. p. 162-211.

BOURDIEU, Pierre. "O ser social, o tempo e o sentido da existência". In: Meditações Pascalianas. Rio de Janeiro: Bertrand Brasil, 2001. p. 253-300.

BOURDIEU, Pierre. A Economia das Trocas Lingüísticas. São Paulo: EDUSP, 1998. 
BOURDIEU, Pierre. "Esboço de uma teoria da prática". In: Pierre Bourdieu. SP: Ática, 1983. p. 46-81.

BOURDIEU, Pierre. O Poder Simbólico. Rio de Janeiro: Bertrand Brasil, 1989.

CRAPANZANO, Vincent. "Horizontes imaginativos e o aquém e o além". In: Revista de Antropologia, v. 48, n.1. São Paulo: USP, 2005. p. 363-384.

CRAPANZANO, Vincent. "Réflexions sur une anthropologie des émotions". In: Terrain, $\mathrm{n}^{\circ}$ 22, mars 1994. p. 109-117.

DAS, Veena. Critical Events: An Anthropological Perspective on Contemporary India. New Delhi: Oxford University Press, 1995.

DE CERTEAU, Michel. A invenção do cotidiano: artes de fazer. Petrópolis: Vozes, 1994.

DIAS DUARTE, Luiz Fernando. "A construção social da pessoa moderna" In: Da vida nervosa nas classes trabalhadoras urbanas. Rio de Janeiro: Jorge Zahar Editor/Cnpq, 1986. p. 35-58.

DOUGLAS, Mary. Pureza e Perigo. São Paulo: Perspectiva, 1966.

DUMONT, Louis. $O$ individualismo. Uma perspectiva antropológica da ideologia moderna.

Rio de Janeiro: Rocco, 1985.

DURAND, Gilbert. A imaginação simbólica. São Paulo: Cultrix, 1988.

DURAND, Gilbert. As estruturas antropológicas do imaginário. Lisboa: Presença, 1989.

FOUCAULT, Michel. "A cultura de si”. In: História da Sexualidade 3: o cuidado de si. Rio de Janeiro: Edições Graal, 1985. p. 43-75.

FOUCAULT, Michel. “A Governamentalidade”. In: Microfísica do Poder. Rio de Janeiro: Graal, 1979.

FOUCAULT, Michel. "Introdução. A problematização moral dos prazeres”. In: História da Sexualidade 2: o uso dos prazeres. Rio de Janeiro: Graal, 1984. p. 7-32.

GEERTZ, Clifford. A Interpretação das Culturas. Rio de Janeiro: LTC, 1989.

GEERTZ, Clifford. Negara: O Estado Teatro do Século XIX. Lisboa: Difel, 1991.

GIDDENS, Anthony. "A teoria da estruturação, pesquisa empírica e crítica social. In: $A$ constituição da sociedade. São Paulo: Martins Fontes, 1989. p. 229 a 286.

GOLDMAN, Marcio. "Uma categoria do pensamento antropológico: a noção de pessoa". In: Alguma Antropologia. Rio de Janeiro: Relume Dumara, 1999. p. 21-38.

HALBWACHS, Maurice. A memória coletiva. São Paulo: Vértice, 1990.

LANDÉ, Carl H.. "Introduction. The dyadic basis of clientelism". In: SCHIMIDT, Steffen W. et alii. Friends, followers and factions: a reader. Berkeley: University of California Press, 1977. p. XIII-XXXVII.

LÉVI-STRAUSS, Claude. Antropologia Estrutural. Rio de Janeiro: Tempo Brasileiro, 1970.

LÉVI-STRAUSS, Claude. O Pensamento Selvagem. Campinas: Papirus, 1989.

MAUSS, Marcel. "A expressão obrigatória dos sentimentos". In: CARDOSO DE OLIVEIRA, Roberto (org.). Marcel Mauss [Col. Grandes Cientistas Sociais]. São Paulo: Ática, 1979.

OLIVEIRA, Roberto. Sociologia e Antropologia. São Paulo: Cosac \& Naify, 1974.

MORAES FILHO, E. (Org.). Simmel. São Paulo: Editora Ática, 1987.

POLLAK, Michael. "Memória, esquecimento, silêncio". In: Revista Estudos históricos, v. 2, n. 3. Rio de Janeiro: CPDOC/FGV, 1989. p. 3-15.

PREFEITURA MUNICIPAL DE PORTO ALEGRE. Disponível em: www2.portoalegre.rs.gov.br/ppp. Acessado em: 17.07.2010. Disponível em: http://www2.portoalegre.rs.gov.br/vivaocentro/. Acessado em 18.07.2010.

RICOEUR, Paul. Tempo e Narrativa. Tomo I, II, III. Campinas: Papirus, 1994. 
SAHLINS, Marshall. 'O 'Pessimismo Sentimental' e a Experiência Etnográfica: por que a cultura não é um 'objeto' em via de extinção". In: MANA, v.3, n.1. Rio de Janeiro: PPGAS/Museu Nacional/UFRJ, 1997.p.41-73.

SAHLINS, Marshall. Ilhas de História. Rio de Janeiro: Jorge Zahar, 1990.

SIMMEL, G. "A Filosofia da Paisagem". In: Política \& Trabalho, n. 12. João Pessoa: PPGS/UFPB, 1996. pp. 15-24.

SOUZA LIMA, Antonio Carlos (org.). "Introdução". In: SOUZA LIMA, Antonio Carlos. Gestar e Gerir. Rio de Janeiro: Relume Dumará, 2002.

TAYLOR, Charles. "Configurações incontornáveis"; "O self no espaço moral”. In: TAYLOR, Charles. As fontes do Self: a construção da identidade moderna. $2^{\mathrm{a}}$ Ed. Loyola: São Paulo, 2005. pp. 15-76.

TURNER, Victor. Dramas, Campos e Metáforas. Niterói: Ed. UFF, 2008.

TURNER, Victor. Floresta de Símbolos: aspectos do ritual Ndembu. Niterói: Ed. UFF, 2005. TURNER, Victor. O Processo Ritual: estrutura e antiestrutura. Petrópolis: Vozes, 1974.

VELHO, Gilberto. "Trajetória Individual e campo de possibilidades". In: Projeto $e$ metamorfose. Antropologia das sociedades complexas. Rio de Janeiro: Jorge Zahar, 1994.

VELHO, Gilberto. Individualismo e cultura. Notas para uma antropologia da sociedade contemporânea. Rio de Janeiro: Zahar, 1981.

WAGNER, Helmut R. (Org. e Introdução). Fenomenologia e relações sociais. Textos escolhidos de Alfred Schutz. Rio de Janeiro: Zahar, 1979.

ZUMTHOR, Paul. Performance, Recepção, Leitura. São Paulo: EDUC, 2000.

Recebido em: 20/12/2010

Aprovado em: 28/03/2011 